\title{
Oogenesis and Egg Quality in Finfish: Yolk Formation and Other Factors Influencing Female Fertility
}

\author{
Benjamin J. Reading 1,2,*, Linnea K. Andersen ${ }^{1}$, Yong-Woon Ryu ${ }^{3}$, Yuji Mushirobira ${ }^{4}$, \\ Takashi Todo ${ }^{4}$ and Naoshi Hiramatsu ${ }^{4}$ \\ 1 Department of Applied Ecology, North Carolina State University, Raleigh, NC 27695, USA; \\ lkander5@ncsu.edu \\ 2 Pamlico Aquaculture Field Laboratory, North Carolina State University, Aurora, NC 27806, USA \\ 3 National Institute of Fisheries Science, Gijang, Busan 46083, Korea; ryu.yongwoon@gmail.com \\ 4 Faculty of Fisheries Sciences, Hokkaido University, Minato, Hakodate, Hokkaido 041-8611, Japan; \\ y.mushirobira@nagasaki-u.ac.jp (Y.M.); todo@fish.hokudai.ac.jp (T.T.); naoshi@fish.hokudai.ac.jp (N.H.) \\ * Correspondence: bjreadin@ncsu.edu; Tel.: +1-919-515-3830
}

Received: 28 August 2018; Accepted: 16 November 2018; Published: 21 November 2018

\begin{abstract}
Egg quality in fishes has been a topic of research in aquaculture and fisheries for decades as it represents an important life history trait and is critical for captive propagation and successful recruitment. A major factor influencing egg quality is proper yolk formation, as most fishes are oviparous and the developing offspring are entirely dependent on stored egg yolk for nutritional sustenance. These maternally derived nutrients consist of proteins, carbohydrates, lipids, vitamins, minerals, and ions that are transported from the liver to the ovary by lipoprotein particles including vitellogenins. The yolk composition may be influenced by broodstock diet, husbandry, and other intrinsic and extrinsic conditions. In addition, a number of other maternal factors that may influence egg quality also are stored in eggs, such as gene transcripts, that direct early embryonic development. Dysfunctional regulation of gene or protein expression may lead to poor quality eggs and failure to thrive within hours of fertilization. These gene transcripts may provide important markers as their expression levels may be used to screen broodstock for potential spawning success. In addition to such intrinsic factors, stress may lead to ovarian atresia or reproductive failure and can impact fish behavior, fecundity, and ovulation rate. Finally, postovulatory aging may occur when eggs become overripe and the fish fails to spawn in a timely fashion, leading to low fertility, often encountered during manual strip spawning of fish.
\end{abstract}

Keywords: egg quality; vitellogenin; aquaculture; fish; fertility; oogenesis; yolk; reproduction

\section{Introduction}

Reproductive fitness is a critical component to the success of wild and domestic animals and egg quality of fishes has been a topic of research for decades in regards to aquaculture and fisheries. The study of egg quality is complex, as "quality" can be defined in different contexts and also is influenced by a variety of factors both intrinsic and extrinsic to the animal. The term egg quality has generally been defined as the ability of developmentally competent eggs to produce viable embryos once fertilized by a sperm [1-4]. Although simple in context, this is a much more complicated concept to understand in practice. The intent of this review is to provide an overview of oogenesis, yolk formation, ovarian maturation, and ovulation with special attention paid to our understanding of how these processes may become dysfunctional leading to poor egg quality. Identifying what makes a "poor quality" egg first requires an understanding of how a "good quality" egg is formed. 


\section{Ovarian Growth and Yolk Formation}

Growth of ovarian follicles can be broadly divided into previtellogenic and vitellogenic growth stages, during which the major lipid and protein nutrients required for embryonic and larval development are stored within the oocyte (this review will generally follow those processes outlined in Figure 1). Previtellogenic oocytes begin to accumulate neutral lipids, which are stored as lipid droplets in the ooplasm, and also accumulate maternal gene transcripts, which function to direct early embryonic development shortly following fertilization. Vitellogenic stage oocytes accumulate phospholipid-rich lipoproteins, which are stored as yolk inclusions in the ooplasm. When vitellogenesis ends, the ovary is filled with fully yolked oocytes that subsequently undergo maturation and ovulation. The entire period encompassed by previtellogenic and vitellogenic growth is typically a critical timeframe for captive broodstock management as appropriate conditioning and diet are required for the animals to produce good quality eggs.

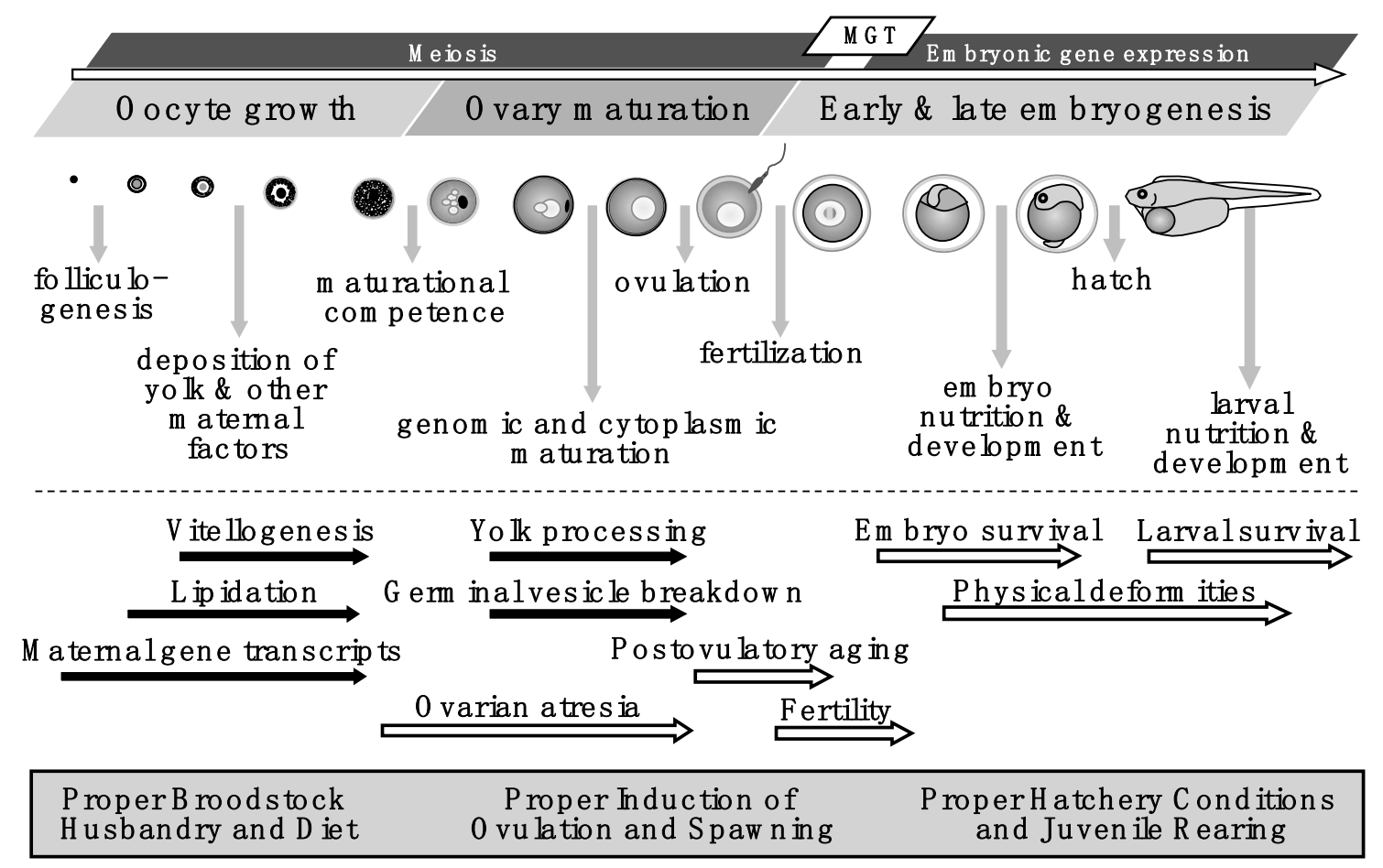

Figure 1. Model depicting the summary of processes and events during oocyte growth, ovary maturation, and early and late embryogenesis in fishes. Vertical grey arrows indicate critical physiological events, horizontal black arrows indicate important processes, and open arrows indicate potential problems or evaluations of egg quality. These topics are detailed in corresponding sections of this review and the figure has been compiled from several studies including those on: folliculogenesis, vitellogenesis, lipidation, and yolk processing [5-41]; maternal gene transcripts [2-4,42-51]; maturational competence, germinal vesicle breakdown, cytoplasmic maturation, and ovulation [15,25,26,30,31,35,52-57]; ovarian atresia (including broodstock stress) [48,52,58-70]; postovulatory aging [48,71-85]; and methods of evaluating egg quality including fertility, embryo survival, larval survival, and incidence of physical deformities $[3,42,43,45-51,86]$. Proper broodstock husbandry and diet, conditioning for spawning, ovulation, fertilization, and hatchery conditions are required to produce high quality eggs, see also: [1,3,15,25,52,53,58,87-131]. MGT $=$ translation of maternal gene transcripts.

In many teleosts, large amounts of neutral lipids are accumulated in oocyte lipid droplets during early oocyte growth in a process termed 'oocyte lipidation'. The occurrence of lipid droplets is generally first observed at the previtellogenic oocyte growth stage, and ongoing accumulation continues as development proceeds through vitellogenesis [132]. Recent studies in Japanese eel (Anguilla japonica) [5], shortfinned eel (Anguilla australis) [6], cutthroat trout (Oncorhynchus clarkii), [7], medaka, 
(Oryzias latipes) [7], black skipjack tuna (Euthynnus lineatus) [7] and seaweed pipefish (Syngnathus schlegeli, have shown that very low density lipoprotein (VLDL) is the primary carrier of the neutral lipids into oocytes. A hypothetical model for the molecular mechanism underlying the formation of oocyte lipid droplets has been proposed as follows (Figure 2, see also [7,8]): (1) VLDL is metabolized by the action of lipoprotein lipase (LPL), a key enzyme of VLDL metabolism, in the ovarian follicle cells (especially granulosa cells) to generate free fatty acids, (2) the free fatty acids are incorporated into growing oocytes through fatty acid translocators and/or fatty acid transporters, (3) the free fatty acids are then transferred to the endoplasmic reticulum by cytosolic fatty acid binding proteins located in the ooplasm, and (4) neutral lipids are synthesized from the free fatty acids and lipid droplets are formed in the oocyte endoplasmic reticulum.

The importance of LPL during oocyte lipidation has been indicated in several fish species. It has been shown that both ovarian LPL activities and $l p l$ gene transcript levels increase in association with the progress of oocyte lipidation and/or oocyte growth $[9,10,133,134]$. Dominant expression of $l p l$ gene transcripts has been observed in previtellogenic and vitellogenic ovarian follicle cells, especially granulosa cells in European sea bass (Dicentrarchus labrax) [9], cutthroat trout [10], medaka, and seaweed pipefish. Interestingly, in zebrafish (Danio rerio), a teleost exhibiting no lipid droplets in the oocytes [135], apparent expression of $l p l$ transcript was hardly observed in the ovarian follicle cells by in situ hybridization, although $l p l$ transcripts were present in the vitellogenic and non-vitellogenic ovaries at detectable levels by PCR amplification [136]. Taken together, these results strongly support the hypothesis that VLDL is metabolized by LPL action at the exterior of the oocyte, especially within the granulosa cells of the follicle.

Further direct evidence has also been reported to support this LPL-dependent model of oocyte lipidation. Histological tracing studies using dual fluorescent-labeled VLDL revealed that only the lipid components of VLDL were incorporated into oocytes, while protein components of VLDL (apolipoproteins) remained outside of the oocyte proper showing that VLDL is not endocytosed into the cell [7]. This lipase-dependent, non-endocytotic pathway was evident in cutthroat trout, medaka, black skipjack tuna, and pipefish, thus indicating that the pathway may be common in teleosts that accumulate lipid droplets within the oocytes. However, in shortfinned eel, it has been shown that low-density lipoprotein receptor (Ldlr) appears to be involved in the processes of oocyte lipidation [6], although the receptor-mediated endocytosis of VLDL into oocytes has not been verified in this species. It should be noted that there are apparent differences between fish species in regard to the endocrine controls of oocyte lipidation. For example, both VLDL and an androgen, 11-ketotestosterone, are required to induce oocyte lipidation in cultured ovarian follicles of eels $[5,6]$, while such effects of androgens on oocyte lipidation are not observed in cutthroat trout. One of the possible actions of androgens on oocyte lipidation in eels has been suggested to induce the expression of the ovarian $l p l$ gene [134]. The endocrine control of oocyte lipidation in fishes is largely unknown and thus remains to be verified in teleosts other than eels. Accumulation of neutral lipids in the ooplasm proceeds continuously with uptake of the egg yolk precursor vitellogenin and appears to be relatively insensitive to disruption of photothermal conditions in white perch (Morone americana) $[52,137]$. Therefore, the mechanisms regulating oocyte lipidation may be different from that regulating vitellogenesis in fishes. 


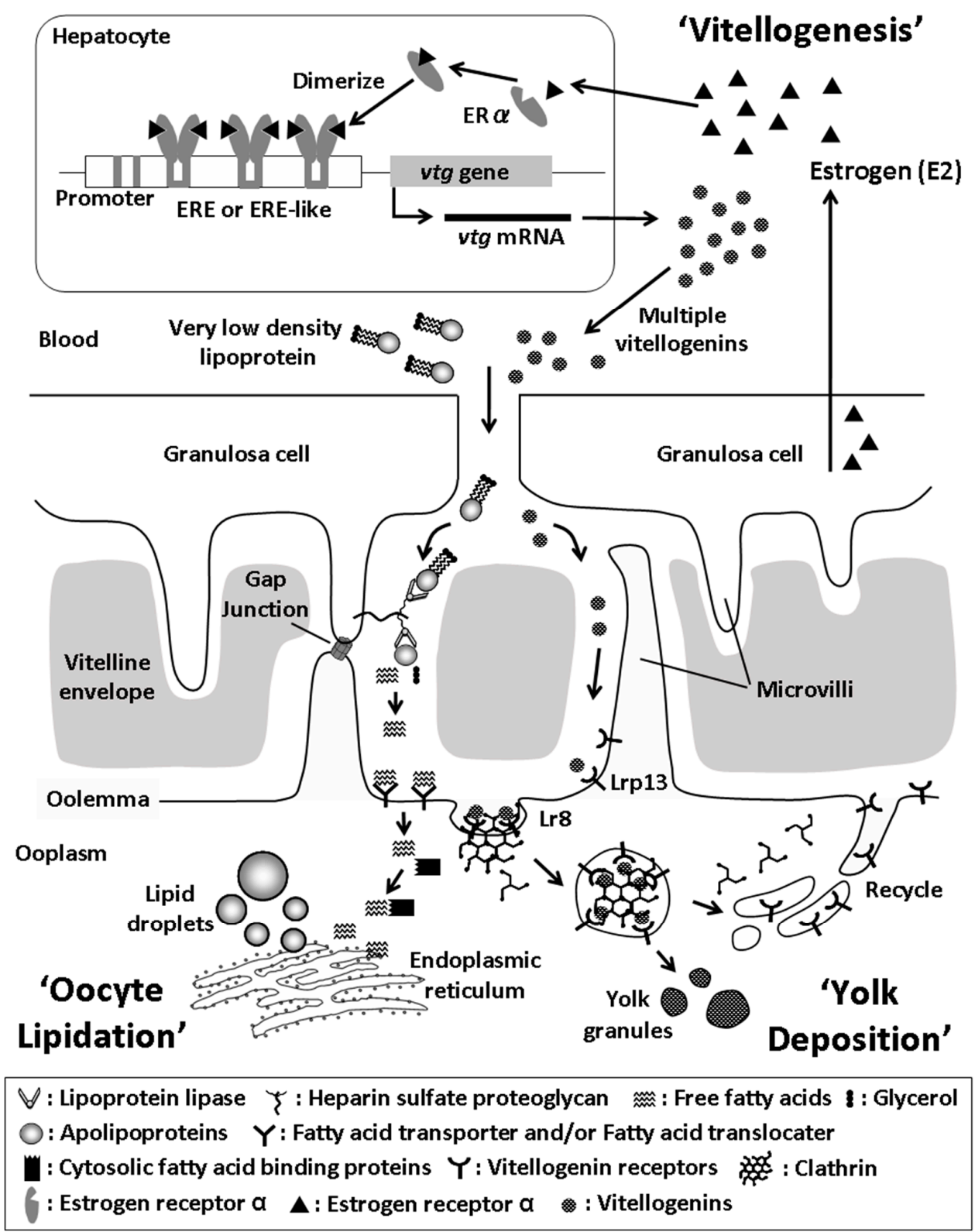

Figure 2. Model of oogenesis depicting 'Oocyte Lipidation', which occurs during previtellogenesis and 'Yolk Deposition', which occurs during 'Vitellogenesis'. Circulating very low density lipoprotein is processed by lipoprotein lipase anchored to heparin sulfate proteoglycan within the ovarian follicle cell layer. Free fatty acids then cross over the oolemma escorted by fatty acid transporter and/or fatty acid translocator proteins where they are transferred to the endoplasmic reticulum by cytosolic fatty acid binding proteins located in the ooplasm. Free fatty acids are then re-esterfied and stored within lipid droplets or inclusions located throughout the ooplasm (Oocyte Lipidation). Estrogen (E2) produced by the ovarian follicle granulosa circulates to the liver where it enters into hepatocytes and binds an estrogen receptor. The estrogen receptors dimerize and bind estrogen response elements (EREs) or ERE-like sequences in the gene promoter regions to initiate transcription of multiple types of vitellogenins (Vitellogenesis). Vitellogenin gene transcripts are translated and mature particles are secreted into the blood where they travel to the ovary and bind specific membrane vitellogenin receptors (Lr8 and Lrp13). Vitellogenin receptors cluster into clathrin coated vesicles that are endocytosed and vitellogenins are processed into yolk proteins for storage in yolk granules located throughout the ooplasm (Yolk Deposition). The figure summarizes data from: [5-22,25,28-31,134]. 
Vitellogenins are phospholipid-rich yolk protein precursors produced by the liver and accumulated by the oocyte during the processes of vitellogenesis. Vitellogenesis is a seasonal or cyclic process regulated by the reproductive hypothamalamic-pituitary-gonadal neuroendocrine axis [53]. Production of gonadotropin-releasing hormone (GnRH) by the hypothalamus of the brain is stimulated by a variety of endogenous and environmental factors, including the innate biorhythm of the fish, bioenergetic status, and seasonal changes in photoperiod and water temperature as examples. Follicle-stimulating hormone (FSH) is secreted by pituitary gonadotrophs in response to GnRH and FSH then induces the ovarian follicle to secrete estradiol-17 $\beta$ (E2). Circulating E2 enters liver cells and binds to an estrogen receptor (ER), which changes conformation and dimerizes. The dimerized ER/E2 complexes bind estrogen response elements (EREs) or incomplete ERE (ERE-like) sequences in the promoter region of the vitellogenin gene, leading to initiation of gene expression and vitellogenin synthesis [138]. The transcriptional potential of different vitellogenin genes seems to be determined by the number of ERE or ERE-like sequences within the promoter region of each, as well as numbers and/or types of additional transcription factor binding sites, such as GATA. These promoter components and structures differ across fish species, as well as among discrete vitellogenin gene subtypes within a species $[11,139,140]$. In teleosts, there are several forms of estrogen receptor [141]. The ER $\alpha$ seems to play an important role in the transcription of vitellogenin genes, because expression of hepatic ER $\alpha$ mRNA is up-regulated by E2 stimulation [11,12,138,142]. However, ER $\alpha$ is not the only ER subtype to regulate vitellogenin gene expression; ER $\beta$ subtypes also have been suggested as essential factors to promote vitellogenin synthesis $[143,144]$. In a representative primitive oviparous vertebrate, the inshore hagfish (Eptatretus burgeri), two kinds of ER cDNAs have been isolated from the liver [145]. These ERs were found to bind E2. In addition, functional ERE-like motifs were also present in the promoter region of hagfish vitellogenin gene. These indicate that the hagfish, like other oviparous vertebrates, acquires the basic E2/ER system for promoting vitellogenin synthesis. However, E2 and ER may not be the only factors that induce vitellogenin production in this species, because (1) hepatic vitellogenin mRNA levels of the female hagfish did not show any significant correlation with hepatic ER mRNA levels nor serum E2 levels; (2) E2 implantation in vivo in male and immature hagfish did not up-regulate hepatic ER mRNA expression, and (3) treatment by E2 weakly induced hepatic vitellogenin mRNA expression, only reaching $1 / 15$ of the levels found in wild-caught vitellogenic females [146]. Collectively, the E2/ER-dependent model of vitellogenin synthesis is typical, but not universal across all oviparous vertebrates, especially in the case of less derived fishes. In some fish species, vitellogenesis might be regulated by other factors as well, for example hagfish produce vitellogenins following feeding and may have limited response to estrogen compared to other fishes $[145,146]$

Mature vitellogenins produced in hepatocytes are then released into the circulatory system where they travel to capillaries of the ovarian follicle and contact with the oolemma. Vitellogenins then enter growing oocytes via endocytosis mediated by specific membrane vitellogenin receptors [13-15]. The first described fish vitellogenin receptor is a member of the lipoprotein receptor superfamily that is characterized by having eight ligand-binding repeats (Lr8), a feature typical of other vertebrate vitellogenin receptors and that of the very low-density lipoprotein receptor (Vldlr) [15-18]. The highest Lr8 mRNA expression typically occurs during previtellogenesis and Lr8 expression then decreases or is absent in late-vitellogenic follicles or ovulated eggs. Translated receptor proteins are translocated near the oolemma in oocytes at the lipidic growth stage or earlier [19], however, activity of receptor-binding to vitellogenin is not detected until transition into vitellogenic growth. Lack of Lr8 gene expression during vitellogenesis suggests that the receptors are recycled to the oocyte membrane after binding vitellogenins and are reused throughout vitellogenic growth. A second form of vitellogenin receptor called Lrp13 also has been reported in fishes and in some species the Lr8 and Lrp13 bind different vitellogenin ligands [13-15,20]. Generally, the Lrp13 gene and protein expression mirrors that of the Lr8 receptor in Acanthomorph [14] and salmonid [20] species. Once vitellogenins bind their receptors, the complexes are endocytosed in cluster in clathrin-coated vesicles that fuse with lysosome-like 
organelles to form multivesicular bodies [15,21]. Inactive cathepsin D zymogens then colocalize in the imported vitellogenins. Vacuolar ATPases then acidify the lumen of the multivesicular bodies and the resulting drop in $\mathrm{pH}$ activates cathepsin $\mathrm{D}$, which cleaves vitellogenin into yolk proteins, which are stored in yolk granules, globules, platelets, or as fluid yolk in the ooplasm [22].

Aberrant cathepsin D activity is linked to poor quality eggs in gilthead seabream (Sparus aurata) likely due to inappropriate yolk protein processing that leads to lack of buoyancy in the ovulated eggs [23]. In fruit fly (Drosophila melanogaster), mutations of the Lr8 receptor homolog are responsible for the yolkless female phenotype, which is characterized as infertile [147]. Severe examples of yolkless mutants in fishes have not been reported, however disruption of the proper cues required for captive broodstock conditioning, such as photothermal parameters that stimulate vitellogenesis and receptor mediated uptake of vitellogenins by the oocyte, do result in abnormal oocyte and egg development. White perch is a temperate fish from the northern hemisphere that initiates vitellogenesis in the fall (shortening daylight and decreasing temperature) and spawns in the springtime (lengthening daylight and increasing temperature). When these fish are reared at a constant temperature and photoperiod the oocytes will accumulate neutral lipids (previtellogenic growth), however they will not accumulate vitellogenin-derived egg yolk [52,137]. A similar finding was reported in Eurasian perch (Perca fluiatilis), whereby constant photothermal conditions inhibited vitellogenesis [148]. This dysfunction is likely due to a disruption of vitellogenesis and/or receptor mediated uptake of vitellogenins, as both of these processes are under regulation by E2, which is released following gonadotrope signaling from the brain based on proper photothermal conditioning. In Eurasian perch, constant photoperiod was accompanied by lower levels of testosterone, E2, and 11-ketotestosterone (11KT) [148], which further supports this contention. Therefore, understanding the natural biology of the fish is required for production of adequately yolked eggs of high quality and successful captive breeding of broodstock. Care should be taken to appropriately condition fish for the reproductive cycle (or to artificially shift fish from the natural cycle) and for some species this may be several to many months in advance of the spawning time.

\section{Multiplicity of Fish Vitellogenins}

Fish vitellogenins have a complex evolutionary history and multiple types have arisen via whole genome duplications in the vertebrate lineage. These different vitellogenins exhibit considerable variation in structure and function between fish taxa, which is beyond the scope of this review, but further information can be found in Matsubara et al., Finn and Kristoffersen, Finn, Reading et al., Reading and Sullivan, and Reading et al. $[15,24,25,54,149,150]$. In short, fish vitellogenins are not a simple "food" for embryos, but rather they are involved in other complex functions such as providing an osmotic gradient to drive hydration for establishing proper egg buoyancy and metabolic water for embryonic development. They also provide a programmed provisioning of protein, carbohydrate, and lipid nutrition to developing embryos and yolk sac larvae at different developmental time points. A disparate accumulation by the oocyte of different vitellogenin type has also been reported in several species of fishes including grey mullet (Mugil cephalus) [55], barfin flounder (Verasper moseri) [26,27], striped bass (Morone saxatilis) [28,151], white perch [29,54], mosquitofish (Gambusia affinis) [30], red seabream (Pagrus major) [31], goldsinny wrasse (Ctenolabrus rupestris) [152], haddock (Melanogrammus aeglefinus) [32], Atlantic halibut (Hippoglossus hippoglossus) [33,153], and zebrafish (Danio rerio) [34]. This indicates that the final egg yolk composition may vary considerably between fish species. Such yolk variation may relate to early life history traits of fishes, such as different requirements for egg buoyancy, larval nutrition, or time frame until first feeding. Additionally, white perch reared in water with less than 5 ppt salinity have a differing proportion of vitellogenin derived yolk proteins compared to perch reared in brackish water. This suggests that the vitellogenin egg yolk system in some fish species may be sensitive to water salinity and thus physiologically regulated for production of eggs with appropriate buoyancy based on the salinity of the water [29]. The system of Lr8 and Lrp13 ovary receptors, along with expression of multiple vitellogenin types by the liver regulate this differential 
vitellogenin accumulation in the egg yolk $[15,28,29]$. Therefore, vitellogenin derived egg yolk is critical not only to providing an adequate nutritional reserve for embryonic development, and thus is related to broodstock diet, but also influences egg buoyancy and thus is responsive to husbandry conditions such as photoperiod, water temperature, and salinity. These conditions must be closely monitored during broodstock conditioning along with providing an adequate diet during previtellogenesis and, importantly, vitellogenesis.

\section{Ovarian Maturation and Proteolysis of Yolk Proteins}

After vitellogenesis completes, oocytes enter a period generally characterized by translational quiescence called post-vitellogenesis [154]. During this time, many of the oocyte ribosomes disassemble and/or translocate from the ooplasm and the ovarian follicle prepares for ovulation, which includes acquisition of maturational competence. Maturational competence is required for the oocyte to complete maturation and ovulate in response to a progesterone signal [52,53]. Gonadotropin-releasing hormonereleased by the hypothalamus stimulates luteinizing hormone (LH) secretion by the pituitary and LH then induces the ovarian follicle to secrete a progesterone, typically either $17 \alpha, 20 \beta$, 21-trihydroxy-4-pregnen-3-one (20 $\beta$-S) or $17 \alpha, 20 \beta$-dihydroxy-4-pregnen-3-one (17 $\alpha, 20 \beta$-DHP) [56]. The activities of these progesterones for inducing ovarian maturation and ovulation in fishes is species specific.

Ovarian maturation consists of two processes that occur vis-a-vis, (1) genomic maturation including resumption of meiosis, germinal vesicle migration and breakdown, and (2) cytoplasmic maturation, which includes the coalescence of lipid droplets, clarification of the ooplasm, and hydration of the oocytes [52,53]. Genomic maturation is required for the oocyte to complete the meiotic reduction division following fertilization and failure to complete germinal vesicle breakdown typically results in an infertile egg or anovulation (failure to ovulate). A secondary yolk proteolysis occurs during cytoplasmic maturation in fishes that spawn pelagic (floating) eggs, whereby some of the vitellogenin-derived yolk proteins are proteolyzed into free amino acids or small peptide fragments $[15,25,26,31,35,55,57]$. In fishes spawning demersal (sinking) eggs, live bearers, and fishes in less derived taxa, maturational yolk proteolysis is not as extensive and many of the yolk proteins remain intact or are cleaved into large peptides $[15,30,54]$. Maturational proteolysis of the yolk proteins requires acidification of yolk vesicles by vacuolar $\mathrm{H}^{+}$-ATPase, which activates cathepsin proenzymes located therein $[15,53]$.

Cathepsins B, F, and L have been shown to be involved in maturational yolk proteolysis in mummichog (Fundulus heteroclitus). Cathepsin F, however, is only found in yolk granules during vitellogenesis and, therefore, it may play a role in the activation of either cathepsins B or L or both [155]. The proteolytic activities of cathepsins B and L related to the cleavage of vitellogenin-derived yolk proteins may also be species specific. In barfin flounder (Verasper moseri), cathepsin B mediates this proteolysis [149] however, in gilthead seabream (Sparus aurata) cathepsin L does [36,37]. Dysfunctional cathepsin D and L levels in ovulated eggs and recently fertilized embryos are related to low fertility in seabream [38]. Low levels of cathepsin D and cathepsin B expression in recently fertilized red spotted grouper (Ephinephelus akaara) embryos (0-24 h post-fertilization) also are associated with poor egg quality [39], further suggesting that proper processing of vitellogenin derived yolk proteins is a critical step during vitellogenesis and ovarian maturation and may lead to reproductive failure if disrupted.

The small peptides and free amino acids generated during maturational yolk processing, along with inorganic ions, act as osmotic effectors that drive an influx of water into the oocyte [26,32,52]. Water diffuses through aquaporins in the oocyte membrane [40,41], and this influx of water results in oocyte hydration and proper egg buoyancy. This hydration also provides metabolic water for dilution of embryonic waste products and an increased egg volume to allow an adequate space for embryonic development. The yolk protein-derived free amino pool also is used as a source of diffusible nutrients for embryos during the earliest developmental stages, while any remaining larger yolk proteins and 
lipid droplets provide nutrients for later stage embryos and larvae once the yolk syncytium has formed [15]. The lipid droplets also contribute buoyancy to the egg as well.

Understanding the female reproductive cycle for individual species also is important for identifying the critical time frame for administering pharmaceuticals to induce spawning, such as GnRH, LH, or human chorionic gonadotropin (hCG). These hormones (or their analogs) must be administered appropriately for successful captive reproduction and high egg quality. For example, GnRH or LH act at the level of the brain or pituitary and can offer a slower, global conditioning effect on the female fish $[58,87,88]$. These hormones will act to eventually stimulate progesterone production by the follicle and other downstream responses that will bring on ovarian maturation and ovulation in most species. In contrast, hCG mimics the effects of progesterone and thus the ovary must already be maturationally competent to initiate ovarian maturation (competence to respond to the progesterone signal) in order to successfully induce ovulation $[53,89,90]$. At present there are no known effective hormonal treatment regimes to fully condition a complete female reproductive cycle for fishes in captivity, such as treating with E2 to complete vitellogenesis and then using a different hormone to induce ovulation. Treatment with E2 will stimulate vitellogenin synthesis and secretion by the liver [91], however it is not practically used to induce broodstock to complete vitellogenesis in aquaculture conditions. Photothermal or other environmental manipulations during broodstock husbandry are typically the successful approach to achieving this. One famous paper describes the use of pituitary extracts to induce ovarian growth and maturation in eel [92], as eels notoriously do not proceed through vitellogenesis under any captive conditions without pituitary extract treatment. To induce ovarian maturation, $17 \alpha, 20 \beta$-DHP is typically injected into female eels at the post-vitellogenic stage.

The postovulatory follicle method [93] or other preovulatory staging methods [94,95] may be used to estimate spawning time to better identify the best hormonal treatment and timing for inducing ovulation in captive reared fishes. The postovulatory follicle method uses histology to observe postovulatory follicles in order to estimate the time of spawning. Protocols and sets of criteria have been developed to predict ovulation in species such as rockfish (Sebastodes paucispinus), northern anchovy (Engraulis mordax), zebrafish (Danio rerio), striped bass, and others [93,96-98]. Histological post- and pre-ovulatory analyses require species-specific procedural development, expertise, and care needs to be taken to minimize estimate bias by personnel and/or the use of multiple confounding criteria or standards. Additionally, protocols and identifying keys have been developed for staging that can take place in a production setting such as that described in Harrell et al. (1990), which pertains to the culture of pure and hybrid striped bass [99]. Other methods to evaluate competence to respond to progesterone (maturational competence) include incubating ovarian fragments sampled from the fish in vitro with hormones and then evaluating a response such as germinal vesicle migration or breakdown $[89,90]$. A positive response of the in vitro assay indicates that the female fish is ready to be treated for spawning induction.

\section{Egg Yolk Composition and Broodstock Diet}

The contribution to oocyte growth of Vtg-derived yolk can be substantial, comprising up to $80-90 \%$ of the dry mass of an ovulated egg in some species [15]. Vitellogenins consist of phosphate, lipid (about $20 \%$ by weight), carbohydrate, and protein components and are members of the large lipid transfer protein superfamily, which includes other serum lipoproteins such as low-density lipoprotein (LDL) and VLDL [156]. Alanine is the most abundant amino acid comprising about 11 to $12 \%$ of the total residues of vitellogenin polypeptides. In some species, such as eels the vitellogenins contain polyalanine regions [54]. Alanine may serve as an important intermediary of carbohydrate metabolism, especially for embryonic gluconeogenesis. Vitellogenins also are carriers of important ions, including calcium, magnesium, iron, zinc, copper, and various minerals and vitamins, such as retinoids and carotenoids $[24,100]$. Metal ions are not abundantly available for uptake in freshwater environments, and therefore, ion transport by vitellogenins is crucial for embryo survival in species such as masu 
salmon (Oncorhynchus masou) and mosquitofish, In contrast, the egg yolk of marine fishes, such as red seabream, barfin flounder, and Pacific herring (Clupea pallasii), contains less of the metal ions abundantly present in seawater, such as calcium and magnesium, suggesting that vitellogenin may play a less significant role in the provision of these ions to embryos of marine fishes [15]. For fishes that spawn demersal (sinking) eggs that lack prominent oil droplets, vitellogenins are major carriers of lipids into growing oocytes, most of which (about $80 \%$ ) are phospholipids. In marine fishes that spawn pelagic eggs with no large oil droplets, phospholipids, triacylglycerides, and wax- or steryl-esters can account for over $70 \%, 8 \%$ to $12 \%$, and about $4 \%$ of total egg lipids, respectively. Other fishes may produce pelagic eggs with large oil droplets comprised of neutral lipids, often triacylglycerides and wax- or steryl-esters, that can occupy over $50 \%$ of the ooplasm. In addition to serving as energy reserves, these lipids provide buoyancy for the pelagic eggs, particularly in the case of the golden perch (Macquaria ambigua) [157].

It is well known that broodstock nutrition can influence reproductive performance, including but not limited to timing of reproductive season, fecundity, spawning frequency, egg yolk composition, and egg quality in fishes [1]. The impact of diet on reproductive behavior and/or egg quality, however is uncertain for some aquaculture species, especially those for which breeding protocols are not yet established or are still in development, however diet is likely a critical feature to consider when implementing captive breeding programs based on what is already known [3]. Furthermore, the specific effects of diet and nutrition are difficult to determine and evaluate, especially across studies, due to variation in confounding factors such as differences in experimental conditions and methodologies [1]. A change in the timing of reproductive behavior associated with a change in diet may serve as a proximal indicator that there will be a change in observed egg quality, as the two changes are typically observed together [101]. The percentage of crude protein in a broodstock diet has been found to have an effect on time to spawn, fry survival, and lipid content in Nile tilapia (Oreochromis niloticus). Al-Hefedh et al. found that increased dietary protein content up to a certain threshold (40\%) will increase broodstock growth and larval survival, but may decrease broodstock lipid content [102]. It is important to note, however, that fecundity was significantly higher in fish that had been fed a diet with less protein (25-35\% compared to 40-45\%) within this study [102]. Similarly, Watanabe et al. found that the gametes produced by rainbow trout (Oncorhynchus mykiss) were of greater quality when fed a diet of low protein $(30 \%)$ compared to a diet of higher protein $(57 \%)$, although other factors may be involved, such as the percentage of crude lipid was not consistent across diets used in the study [103]. The source of protein is also an important factor to consider when formulating a diet as different species may show improved uptake and utilization of plant-based proteins over animal-based proteins or vice versa [104]. It is known that slightly reducing the dietary protein content or feeding rate of female broodstock during vitellogenesis may improve reproductive output in many fishes. The basis, although speculative, is that when faced with an environmental stressor, such as mild feed restriction, the female will produce better gametes to ensure successful reproduction. Care must be taken when adjusting the broodstock diet, however to not overly restrict nutrition to the animals such that they are unable to dedicate appropriate energy reserves to forming high quality gametes. It is unclear what the effects of this strategy is on future clutches of oocytes in semelparous species, however, in common practice it does not appear to be detrimental, and this also is difficult to scientifically assess.

Lipid composition is also a critical element to a broodstock diet as lipids have vast biological function and serve as structural components of cell membranes, energy storage, and signaling pathways, among other important roles and actions for the embryo and, together with proteins, comprise the majority of egg yolk by weight as aforementioned. The variety of potential lipid functions is due to the great diversity of lipid structure, however, a simple yet comprehensive classification for lipids breaks them down into the three main groups of homolipids such as fats and oils like triglycerides and waxes, heterolipids such as phospholipids and glycolipids, and derived lipids, which includes steroids, cholesterol, terpenes, and carotenoids [105]. Some lipids also serve as a source or 
carrier of vitamins that have been shown to be an important part of the broodstock diet for egg quality, development, and larval survival as summarized here.

Essential fatty acids that comprise homolipids and heterolipids are necessary for embryonic and larval development and survival, however, the best source and concentration of fatty acids in the broodstock diet is also species specific [106,107]. Furthermore, the required n-3 highly unsaturated fatty acids (HUFA) is thought to be dependent on the initial maternal contribution to the egg $[108,109]$. The incorporation of polyunsaturated fatty acids (PUFAs) into the diet is of particular importance, because fish are unable to synthesize them [1]. Freshwater species, particularly those living at warmer temperatures, have been found to require linoleic acid 18:2 (n-6) and alpha-linolenic acid 18:3 (n-3), whereas marine species require eicosapentaenoic acid 20:5 (n-3) and docosahexaenoic acid 22:6 $(n-3)$, which are more elongated and unsaturated [110,111]. Eicosapentaenoic acid 20:5 (n-3) and docosahexaenoic acid 22:6 (n-3) in particular have been found to show an effect on egg quality and embryo survival [101,112].

Presence of docosahexaenoic acid 22:6 (n-3) in the broodstock diet was found to increase the percentage of morphologically normal eggs in gilthead bream (Sparus aurata) [113]. In Japanese sea bream (Pagrus major), a broodstock diet lacking in eicosapentaenoic acid 20:5 (n-3) resulted in a reduction in the percentage of good eggs compared to the control diet [103]. European sea bass fed a diet with low levels of n-3 series PUFAs had a lower fecundity and egg viability [113]. However, lower concentrations of eicosapentaenoic acid 20:5 (n-3) were found in white bass (Morone chrysops) ova from broodstock fed a diet with higher $n-6 / n-3$ ratios, and docosahexaenoic acid 22:6 (n-3) was found to preferentially be incorporated within ova over other n-3 PUFAs [114]. Wax esters also are thought to have possible function in egg buoyancy and yolk energy storage [115,116,157].

Heterolipid phospholipids serve as a source of stabilization for free radicals [117] and are integral to cell membrane structure [118], which is critical for rapidly dividing embryos. Phospholipids may also be the primary endogenous energy source in some larval fishes such as rainbow trout, red seabream, and halfbeak (Hemiramphus sajori) [119-121]. Phosphatidylcholine in the broodstock diets of fishes such as halibut (Hippoglossus hippoglossus), plaice (Pleuronectes platessa), and cod (Gadus morhua) [118], may serve as a source of inorganic phosphate and choline [122]. Phosphatidylcholine also is a major component of the lipid cargo carried by vitellogenins $[15,25,100]$ and thus may be critical for embryonic development.

Carotenoids are derived lipids that serve as a source of vitamin A. In the presence of vitamins, carotenoids serve as protectors against the free radicals that can weaken egg membrane integrity because they act as scavengers of active oxygen species [107]. Although there is little known about the necessity of vitamin A prior to and during spawning, vitamin A has been found to influence bone and retinal formation as well as immune cell differentiation during development [107]. Presumably due to this function, insufficient levels of vitamins $A$ and $E$ have been shown to have negative effects on reproductive performance, maturation, spawning, and larval development in turbot (Scopthalmus maximus) $[107,123,124]$. Despite some supporting evidence, improvement of egg quality due to the presence of carotenoids has not been widely studied and conclusions drawn from completed studies have not been consistent across species or across all types of carotenoids [107]. For example, Craik suggested that egg viability might decrease with limited carotenoid content in rainbow trout [125]. Craik and Harvey, however, suggested that it is unlikely that Atlantic salmon (Salmo salar) egg quality is negatively influenced by a low carotenoid concentration [126]. The specific type of carotenoid in question is also important. Watanabe and Kiron found that the addition of astaxanthin, a keto-carotenoid, did improve egg quality for red seabream, but the inclusion of $\beta$-carotene did not show an effect [117]. Aside from egg quality, carotenoids do compose an important pigment class in fish that supports several functions including spermatozoa movement, among others [107,127-130].

The presence of vitamins A, E (including $\alpha$-tocopherol), and C, and ascorbic acid in broodstock diet all have been shown to influence egg quality in fishes. Dietary $\alpha$-tocopherol, a form of Vitamin E, has been linked to enhanced egg quality as its concentration increases [131,158]. Vitamin E deficiencies 
have led to underdeveloped gonads, reduced hatching rates, and lower larval survival in multiple species such as carp (Cyprinus carpio) [159] and gilthead seabream (Sparus aurata) [107]. Low dietary levels of $\alpha$-tocopherol also lead to decreased fertility and larval survival in fishes as well. Eskelinen showed that vitamin C-enriched diets led to the lowest loss of eggs and fry mortality in Atlantic salmon [160]. Dietary vitamin C supplementation has been shown to advance the synthesis of collagen during embryonic development and positively influence reproduction in rainbow trout [161,162]. Insufficient levels of ascorbic acid have been shown to have detrimental effects on embryonic survival in a number of studies $[107,161,162]$.

\section{Omics of Egg Quality and Maternal Gene Transcripts}

A few studies have been conducted over the past decade to address global differences in the transcriptome or proteome profiles of the developing oocyte or egg in relation to egg quality. Genes shown to be important to egg quality in a number of fish species are summarized in Table 1. Maternal gene transcripts are mRNAs that are deposited into growing oocytes throughout oogenesis, although most are not translated until after fertilization where they direct early embryonic development prior to the mid-blastula transition and activation of embryonic gene expression. The exact timing of maternal gene transcript translation is unclear and may vary by species, as there is limited information on this. Therefore, these components are critical to determining egg quality and their effects can be observed within hours of fertilization. As examples, percent of survival in zebrafish (Danio rerio) embryos was found not to change beyond $24 \mathrm{~h}$ post-spawning, indicating that embryo mortality attributed to maternal factors is generally observed within the first $24 \mathrm{~h}$ of development [86]. Similarly, striped bass embryo mortality associated with dysfunction maternal gene transcripts was observed within $4 \mathrm{~h}$ post-fertilization and mortality did not change by $24 \mathrm{~h}$ post-fertilization [2]. Although this may be species specific as to the timing of the mid-blastula transition, these observations are indicative of a plateau in embryonic death that occurs early in development and associated with maternal gene transcripts. The use of machine learning to identify patterns within transcriptomics data has proven to be a useful tool for identifying associations between maternal gene transcripts present in pre-ovulatory oocytes and egg quality in striped bass [2,4], the functions of which are described in detail below. Chapman et al. and Sullivan et al. demonstrated that expression levels of maternal gene transcripts deposited within the preovulatory (post-vitellogenic) oocyte are just as predictive of egg quality as gene transcripts present in the ovulated egg of striped bass [2,4]. This suggests that these gene transcripts remain intact through the period of ovarian maturation and ovulation and likely serve to direct early embryonic development. Furthermore, the presence of these gene transcripts in the preovulatory ovary may serve as predictors of spawning success and thus may be used to screen broodstock animals for reproductive potential prior to ovulation [2,4].

Many candidate maternal gene transcripts have been shown to be associated with good and poor egg quality in fishes (Table 1). Generally, when considering this entire list of genes, there are four over-represented functional pathways related to egg quality: (1) the ubiquitin ligase and 26S-proteasome pathway, (2) the spliceosome, (3) cell signaling, and (4) cell division, and all four of these are fundamentally linked together [2,4,42]. To begin with, the ubiquitin ligases earmark certain proteins for degradation by the 26S-proteasome, which may include some damaged proteins, but also important signaling molecules that have a short half-life within the cell. Many of these signaling molecules include members of signal transduction pathways including mitogen-activated protein kinases (MAPK or MAP kinases) and cyclins, as examples. MAP kinases communicate signals from cell membrane receptors to the nucleus of the cell. Cyclins are a large group of proteins associated with the cycle of cell division and therefore regulate mitosis and meiosis. The abundance of cyclin B mRNA $(c y c B)$ in rainbow trout oocytes was found to increase with post-ovulatory aging and also was at higher levels in spawns with increased malformation rates [43]. Cyclin-A2 was found to be most abundant in unfertilized eggs and during cleavage in both zebrafish (Danio rerio) and gilthead sea bream $[44,45]$ and $c c n b 3$ and $c c n e 2$ were found to be down-regulated in the ovaries of striped bass 
females spawning poor quality eggs [2]. Cyclin dependent kinases are another important group of signaling molecules that include regulators of the cell cycle and also are involved in regulating gene transcription, RNA processing, and cell differentiation. These cell cycle regulatory proteins often have a short half-life in the cell as once they relay their message, they are then ubiquinated and degraded by the 26S-proteasome so that the signal does not persist. In striped bass, all of the genes associated with the 26S-proteasome were generally down-regulated in the ovary of females spawning poor quality eggs [2]. Therefore, a link has been established between maternal gene transcripts that control cell cycle signaling pathways and that this appears to be dysfunctional in fish that spawn poor quality eggs. The final pathway, the spliceosome is involved in RNA editing and control of transcription and translation [163]. Many of the regulator proteins included in Table 1 also have a role in the splicesosome in addition to other regulatory roles in the cell cycle and cell division. Therefore, cell cycle appears to be an underlying critical pathway in regard to maternal gene transcripts and early embryo mortality associated with poor egg quality in fishes.

Table 1. Genes involved in egg quality of fishes.

\begin{tabular}{|c|c|c|c|}
\hline Species & Gene & Function & Citations \\
\hline Cod & acy3 & expression in kidneys and liver & Rise et al. ${ }^{*}[46]$ \\
\hline Sea bass & alg5 & transferase activity, egg quality & Żarski et al. [42] \\
\hline Striped bass & anapc7 & cell cycle, ubiquitin ligase & Chapman et al. [2] \\
\hline Striped bass & anln & cell division & Chapman et al. [2] \\
\hline Trout & apoc1 & lipoprotein metabolism & Bonnet et al.* [47] \\
\hline Striped bass & apex1 & DNA repair & Chapman et al. [2] \\
\hline Striped bass & arfgap2 & growth factor, signal transduction & Chapman et al. [2] \\
\hline Striped bass & $\operatorname{arpc5}$ & cell division & Chapman et al. [2] \\
\hline Striped bass & $b \operatorname{tg} 1$ & cell cycle & Chapman et al. [2] \\
\hline Sea bream & Cathepsin_S & papain lysosomal endopeptidase & Fernández et al. [106] \\
\hline Several & Cathepsin_Z & $\begin{array}{l}\text { low quality eggs, cancer, } \\
\text { tumorigenesis }\end{array}$ & Fernández et al. [106]; Aegerter et al. [122] \\
\hline Striped bass & ccnb3 & cell cycle, reproduction & Chapman et al. [2] \\
\hline Striped bass & ccne2 & cell cycle, reproduction & Chapman et al. [2] \\
\hline Striped bass & $c d c 26$ & cell cycle regulation & Chapman et al. [2] \\
\hline Striped bass & cdc37 & cell cycle regulation, growth factor & Chapman et al. [2] \\
\hline Striped bass & $c d c 42 b p b$ & cell division & Chapman et al. [2] \\
\hline Striped bass & $c d t 1$ & cell division, malignant tumors & Chapman et al. [2] \\
\hline Striped bass & cebpd & spliceosome & Chapman et al. [2] \\
\hline Several & cenpf & centromere, cell division & Chapman et al. [2];Żarski et al. [103] \\
\hline Striped bass & cenpk & cell division & Chapman et al. [2] \\
\hline Striped bass & $\operatorname{cir} 1$ & spliceosome & Chapman et al. [2] \\
\hline Striped bass & cnpy2 & cell cycle, ubiquitin ligase & Chapman et al. [2] \\
\hline Striped bass & cops4 & COP9 signalosome, cell cycle & Chapman et al. [2] \\
\hline Striped bass & cops5 & COP9 signalosome, cell cycle & Chapman et al. [2] \\
\hline Striped bass & cops6 & COP9 signalosome, cell cycle & Chapman et al. [2] \\
\hline Striped bass & cops8 & COP9 signalosome, cell cycle & Chapman et al. [2] \\
\hline Striped bass & ctnnb1 & cell division, growth factor & Chapman et al. [2] \\
\hline 44Striped bass & cul3 & cell cycle, ubiquitin ligase & Chapman et al. [2] \\
\hline Several & cyclin-A2 & cell regulation, translation & Fernández et al. [45]; Mathavan et al. [44] \\
\hline
\end{tabular}


Table 1. Cont

\begin{tabular}{|c|c|c|c|}
\hline Species & Gene & Function & Citations \\
\hline Trout & $c y c B$ & cell cycle, reproduction & Aegerter et al. ${ }^{*}[43]$ \\
\hline Striped bass & cyld & cell cycle regulation, apoptotic factors & Chapman et al. [2] \\
\hline Halibut & cyp $2 n$ & cytochrome p450 & Mommens et al.* [49] \\
\hline Cod & dcbld1 & discoidin & Rise et al.* [46] \\
\hline Striped bass & $d d b 2$ & $\begin{array}{l}\text { cell cycle, ubiquitin ligase, DNA } \\
\text { repair }\end{array}$ & Chapman et al. [2] \\
\hline Cod & $d d c$ & neurotransmitter metabolism & Rise et al.* [46] \\
\hline Striped bass & eif1ad & cell cycle, spliceosome & Chapman et al. [2] \\
\hline Striped bass & eif3e & $\begin{array}{l}\text { cell cycle, ubiquitin ligase, } \\
\text { spliceosome }\end{array}$ & Chapman et al. [2] \\
\hline Striped bass & eif3k & spliceosome & Chapman et al. [2] \\
\hline Striped bass & eifte2 & spliceosome & Chapman et al. [2] \\
\hline Halibut & eef $1 a 2 b p$ & translation, protein synthesis & Mommens et al.* [49] \\
\hline Striped bass & ergic2 & malignant tumors & Chapman et al. [2] \\
\hline Sea bream & ERK-1 & mitogen activated protein kinase & Fernández et al. [45] \\
\hline Striped bass & esr2 & cell signaling, estrogen receptor & Chapman et al. [2] \\
\hline Striped bass & fbxo9 & cell cycle, ubiquitin ligase & Chapman et al. [2] \\
\hline Striped bass & fibp & growth factor, cell signaling & Chapman et al. [2] \\
\hline Sea bream & ftmt & iron storage, antimicrobial activity & Fernández et al. [45] \\
\hline Sea bass & fucolectin 4 & immune response & Żarski et al. [42] \\
\hline Striped bass & $82 e 3$ & cell cycle, ubiquitin ligase, apoptosis & Chapman et al. [2] \\
\hline Sea bass & $g b a$ & glucosylceramidase & Żarski et al. [42] \\
\hline Sea bass & gcnl1l & glucosylceramidase, egg quality & Żarski et al. [42] \\
\hline Striped bass & $g d f 9$ & growth factors, cell signaling & Chapman et al. [2] \\
\hline Striped bass & gna13 & growth factors, cell signaling & Chapman et al. [2] \\
\hline Striped bass & gnpda1 & growth factor, cell signaling & Chapman et al. [2] \\
\hline Cod & $g s h-p x$ & glutathione peroxidase & Lanes et al.* [50] \\
\hline Striped bass & $g t f 2 f 1$ & spliceosome & Chapman et al. [2] \\
\hline Cod & hacd1 & cardiac development & Rise et al. * [46] \\
\hline Trout & $h c k$ & blood formation, immunse response & Bonnet et al. ${ }^{*}[47]$ \\
\hline Striped bass & hdac1 & cell cycle, cell division & Chapman et al. [2] \\
\hline Cod & hsp70 & stress response & Lanes et al.* $[50]$ \\
\hline Striped bass & hsp90ab1 & stress, spliceosome, cell signaling & Chapman et al. [2] \\
\hline Trout & igf-1 & somatic growth, cell signaling & Aegerter et al. [43];Aegerter et al.* [48] \\
\hline Trout & igf-2 & somatic growth, cell signaling & Aegerter et al.* [43] \\
\hline Trout & igrf $1 b$ & somatic growth, cell signaling & Aegerter et al.* [43] \\
\hline Several & irf7 & immune response & Mommens et al. ${ }^{*}[49]$;Żarski et al. ${ }^{*}[42]$ \\
\hline Sea bream & jnk1 & mitogen activated protein kinase & Fernández et al. [45] \\
\hline Striped bass & jup & cell division & Chapman et al. [2] \\
\hline Sea bass & kctd12 & G-protein receptor, cell signaling & Żarski et al. [45] \\
\hline Striped bass & kifc1 & cell division & Chapman et al. [2] \\
\hline Striped bass & $k m t 5 a(\operatorname{set} d 8)$ & cell division & Chapman et al. [2] \\
\hline Cod & kpna7 & nuclear protein import & Rise et al.* [46] \\
\hline Trout & krt8 & cytoskeleton & Aegerter et al. ${ }^{*}[48]$ \\
\hline Trout & $k r t 18$ & cytoskeleton & Aegerter et al. ${ }^{*}[48]$ \\
\hline Striped bass & $\operatorname{lmn} b 2$ & cell division & Chapman et al. [2] \\
\hline Striped bass & $\operatorname{lsm} 1$ & spliceosome & Chapman et al. [2] \\
\hline Striped bass & $\operatorname{lsm} 7$ & spliceosome & Chapman et al. [2] \\
\hline
\end{tabular}


Table 1. Cont

\begin{tabular}{|c|c|c|c|}
\hline Species & Gene & Function & Citations \\
\hline Striped bass & $\operatorname{ltn} 1$ & cell cycle, ubiquitin ligases & Chapman et al. [2] \\
\hline Striped bass & map $2 k 2$ & mitogen activated protein kinase & Chapman et al. [2] \\
\hline Striped bass & mapre1 & cell division & Chapman et al. [2] \\
\hline Striped bass & mbip & growth factor, cell signaling, MAPK & Chapman et al. [2] \\
\hline Striped bass & $m c l 1$ & apoptosis, ubiquinated-proteins & Chapman et al. [2] \\
\hline Striped bass & metap2 & spliceosome, malignant tumors & Chapman et al. [2] \\
\hline Halibut & $m h c 1 a$ & immune response & Mommens et al.* [49] \\
\hline Halibut & $m h c 2 a$ & immune response & Mommens et al.* [49] \\
\hline Striped bass & mphosph10 & cell cycle, cell division, spliceosome & Chapman et al. [2] \\
\hline Trout & $m r-1$ & hydroxyacyl glutathione hydrolase & Bonnet et al. ${ }^{*}[47]$ \\
\hline Striped bass & mrpl32 & spliceosome & Chapman et al. [2] \\
\hline Striped bass & mrps30 & apoptosis, ubiquinated-proteins & Chapman et al. [2] \\
\hline Halibut & $m s 4 a 8 a$ & cell signaling & Mommens et al.* [49] \\
\hline Striped bass & $m s h 6$ & DNA repair, malignant tumors & Chapman et al. [2] \\
\hline Trout & myo1b & neuronal development & Bonnet et al. ${ }^{*}[47]$ \\
\hline Striped bass & ncapg2 & cell division & Chapman et al. [2] \\
\hline Striped bass & $n c l$ & spliceosome & Chapman et al. [2] \\
\hline Striped bass & nop10 & spliceosome & Chapman et al. [2] \\
\hline Trout & npm2 & histone chaperone, chromatin & Aegerter et al.* [48] \\
\hline Trout & ntan1 & ubiquitin-dependent protein turnover & Bonnet et al.* [47] \\
\hline Striped bass & $n u c b 1$ & growth factors, cell signaling & Chapman et al. [2] \\
\hline Striped bass & nudt21 & spliceosome & Chapman et al. [2] \\
\hline Sea bream & $\mathrm{P} 38 \alpha$ & mitogen activated protein kinase & Fernández et al. [45] \\
\hline Sea bream & P38 & mitogen activated protein kinase & Fernández et al. [45] \\
\hline Striped bass & $p d c l$ & growth factors, cell signaling & Chapman et al. [2] \\
\hline Halibut & $p d-l 1$ & immune response, apoptosis & Mommens et al.* [49] \\
\hline Halibut & $p d p k 1$ & expression in testis & Mommens et al.* [51] \\
\hline Striped bass & pfdn4 & spliceosome & Chapman et al. [2] \\
\hline Trout & phb2 & cell signaling, estrogen receptor & Bonnet et al.* [47] \\
\hline Sea bass & plec & cytoskeletal structure & Żarski et al. [42] \\
\hline Sea bass & polk & DNA repair & Żarski et al. [42] \\
\hline Striped bass & pomp & cell cycle, 26S-proteasome & Chapman et al. [2] \\
\hline Striped bass & prpf39 & spliceosome & Chapman et al. [2] \\
\hline Striped bass & prss 27 & growth factor, cell signaling & Chapman et al. [2] \\
\hline Striped bass & psma7 & cell cycle, 26S-proteasome & Chapman et al. [2] \\
\hline Halibut & psmb9 & cell cycle, 26S-proteasome & Mommens et al.* [49] \\
\hline Striped bass & psmd14 & cell cycle, 26S-proteasome & Chapman et al. [2] \\
\hline Striped bass & ptges3 & Prostaglandin synthesis, spliceosome & Chapman et al. [2] \\
\hline Trout & ptgs2 & Prostaglandin synthesis, cell signaling & Aegerter et al. ${ }^{*}[48]$ \\
\hline Trout & pyc & metabolism & Bonnet et al. ${ }^{*}[47]$ \\
\hline Striped bass & $\operatorname{rad} 23 a$ & $\begin{array}{l}\text { cell cycle, ubiquitin ligase, DNA } \\
\text { repair }\end{array}$ & Chapman et al. [2] \\
\hline Striped bass & rap1b & malignant tumors, growth factor & Chapman et al. [2] \\
\hline Striped bass & $r b m 22$ & cell division, spliceosome & Chapman et al. [2] \\
\hline Striped bass & rchy1 & cell cycle, ubiquitin ligase & Chapman et al. [2] \\
\hline Several & $r n f 213$ & ubiquitin ligase, low quality eggs & Mommens et al.* [49];Żarski et al. [42] \\
\hline Trout & $r p l 24$ & protein synthesis & Bonnet et al. ${ }^{*}[47]$ \\
\hline Striped bass & $r p s 3$ & DNA repair, spliceosome & Chapman et al. [2] \\
\hline Striped bass & $r p s 6$ & protein translation, cell division & Chapman et al. [2] \\
\hline Striped bass & smn & spliceosome & Chapman et al. [2] \\
\hline Striped bass & snrnp 27 & spliceosome & Chapman et al. [2] \\
\hline
\end{tabular}


Table 1. Cont

\begin{tabular}{|c|c|c|c|}
\hline Species & Gene & Function & Citations \\
\hline Striped bass & snrpa & spliceosome & Chapman et al. [2] \\
\hline Striped bass & sprk1 & spliceosome & Chapman et al. [2] \\
\hline Striped bass & $\operatorname{srp} 54$ & spliceosome & Chapman et al. [2] \\
\hline Striped bass & ssx2ip & malignant tumors & Chapman et al. [2] \\
\hline Striped bass & $t b c 1 d 25$ & growth factors, cell signaling & Chapman et al. [2] \\
\hline Striped bass & tcirg1 & malignant tumors & Chapman et al. [2] \\
\hline Striped bass & $t l k 1$ & cell division & Chapman et al. [2] \\
\hline Striped bass & tmbim6 & apoptosis, ubiquinated-proteins & Chapman et al. [2] \\
\hline Striped bass & tollip & cell cycle, ubiquitin ligase & Chapman et al. [2] \\
\hline Striped bass & tsen54 & spliceosome & Chapman et al. [2] \\
\hline Sea bass & $t s f m$ & protein synthesis, egg quality & Żarski et al. [42] \\
\hline Striped bass & tuba3e & cell division & Chapman et al. [2] \\
\hline Several & tub- $\beta$ & cytoskeleton & Aegerter et al.* [48]; Fernández et al. [45] \\
\hline Striped bass & $u b e 2 f$ & cell cycle, ubiquitin ligase & Chapman et al. [2] \\
\hline Striped bass & ube2l3 & cell cycle, ubiquitin ligase & Chapman et al. [2] \\
\hline Striped bass & $u b l 5$ & cell cycle, ubiquitin ligase & Chapman et al. [2] \\
\hline Striped bass & ubox 5 & cell cycle, ubiquitin ligase & Chapman et al. [2] \\
\hline Sea bass & usp5 & cell cycle, ubiquitin ligase & Żarski et al. [42] \\
\hline Striped bass & usp11 & cell cycle, ubiquitin ligase & Chapman et al. [2] \\
\hline Striped bass & usp14 & cell cycle, ubiquitin ligase & Chapman et al. [2] \\
\hline Striped bass & utp18 & spliceosome & Chapman et al. [2] \\
\hline Striped bass & $w d r 3$ & cell cycle, spliceosome & Chapman et al. [2] \\
\hline Halibut & xpo1 & nuclear export of cellular protein & Mommens et al.* [51] \\
\hline Striped bass & znf143 & spliceosome & Chapman et al. [2] \\
\hline
\end{tabular}

Various methodologies have been used to examine and establish the relationship between egg quality and maternal gene transcripts [3]. Aegerter et al., for instance, used survival to eyed- and yolk-sac reabsorption-stage embryos and larvae, respectively, as evaluations of egg fertility in rainbow trout $[43,48]$. These researchers, as well as Lanes et al., used real time-quantitative reverse transcription PCR (RT-qPCR) to identify gene expression differences in rainbow trout pre-ovulatory oocytes and Atlantic cod post-ovulatory eggs, respectively, thus linking certain maternal gene transcripts to egg quality $[43,48,50]$. In contrast, Lanes et al. used hatching rate expressed as a percentage of total eggs to evaluate egg quality in Atlantic cod [50]. Fernández et al. examined eight stages of embryonic and larval development in gilthead sea bream to identify and characterize potential maternal genes using reverse transcription PCR (RT-PCR) and RT-qPCR [45]. Bonnet et al. collected unfertilized eggs from rainbow trout in three treatment groups: natural ovulation, hormone-induced, and photoperiod-manipulation and used a cDNA microarray with 9,152 features to observe differences in egg transcriptome profiles between treatment groups [47]. Eggs from these groups were then fertilized and evaluated for survival and presence of malformations at the timepoint of yolk sac reabsorption [47]. Rise et al. used a microarray with 20,000 features to identify transcriptome differences between female Atlantic cod that produced high and low quality eggs [46]. Total mortality at seven days post-fertilization was used to identify females with the highest and lowest egg quality for comparison and the microarray experiment compared embryos at seven hours post-fertilization [46]. Żarski et al. used a 24,000-feature microarray to analyze expressed gene transcripts in fertilized eggs from European seabass that were either of high ( $>60 \%$ fertilization) or low $(<60 \%$ fertilization) quality [42]. Mommens et al. used suppression subtractive hybridization and RT-qPCR to examine gene transcripts of Atlantic halibut eggs at the point of fertilization and at seven additional stages of development [51]. These investigators used parameters such as blastomere symmetry and hatching success rate to evaluate egg 
quality [51]. Mommens et al. also used a 10,000-feature microarray to examine differentially expressed gene transcripts in Atlantic halibut eggs of high and low hatchability [49]. The samples used in the microarray analysis were collected at four stages post-fertilization [49]. All of these aforementioned studies had slightly different sampling and evaluation protocols, for example, some measured gene expression of pre-ovulatory oocytes whereas others measured expression in post-fertilized embryos or larvae. In most cases, the metrics for egg quality proper were similar, however, hatchability or percent survival at hatch appeared to be the most common metric used. Thus, the methodologies implemented to evaluate egg quality along with the timing of sample collection needs to be considered when comparing studies on egg quality and its association with maternal gene transcripts, as this varies.

In addition to protein coding gene transcripts (mRNAs), other small RNAs called microRNAs (miRNAs) also are deposited into eggs as maternal factors. MicroRNAs are short (19-23 nucleotides), non-coding RNAs that bind mRNAs as targets for degradation and regulation of gene expression [164,165]. The absence of mature miRNAs has been shown to result in embryonic deformities (e.g., lack of subdivision between anterior and posterior axis during development) and poor brain morphogenesis in zebrafish [166]. The absence of miRNAs also has been linked to an insufficient presence of Dicer, a critical RNase III miRNA processing enzyme [164]. Ramachandra et al. identified fourteen miRNAs expressed during embryonic development of rainbow trout with a range of functions including gene targeting during neuronal development (miR-23), reducing pro-apoptotic signaling in hypoxic environments (miR-26), down-regulation of apoptosis-promoting proteins (miR-21), and others [164]. Juanchich et al. similarly identified and characterized thirteen miRNAs with differential expression patterns during oogenesis in rainbow trout that also were identified by Ma et al. [71,165]. Some of the predicted mRNA targets of these miRNAs are known to have a role in oogenesis, ovary maturation, or embryogenesis. MicroRNA miR-301 is down-regulated during oogenesis and was found to target transcripts of steroidogenic acute regulatory protein (star), cathepsin D (ctsd), and potentially adam 8 [165]. Steroidogenic acute regulatory protein is required for ovarian steroid production, including roles such as cholesterol transport to the mitochondria, follicular growth, oocyte maturation $[165,167]$ and star mRNA was found to be up-regulated in the ovarian follicle during oocyte maturation in the rainbow trout $[165,168]$. The importance of cathepsin $\mathrm{D}$ during vitellogenin-derived yolk processing has already been mentioned. A potential target of miR-301, adam 8 is hormonally regulated and expressed in murine granulosa cells, the expression of which is induced by the influx of LH that precedes ovulation $[165,169]$. A similarly expressed gene, smad7 that blocks downstream signal transduction by activating other Smad proteins, is involved in apoptosis in murine granulosa cells and was found to be targeted by miR-181a, miR-92, and miR-101 [165]. The miR-101 along with miR-15, and miR-202 have been shown to target figla in Japanese rice fish (Oryzias latipes), which aids in regulation of expression of several oocyte-specific genes such as those that initiate folliculogenesis, are required for fertilization and early embryonic survival $[165,170,171]$. MicroRNA miR-101 may also target aquaporinla (aqpla), which allows water flow through the cytoplasmic membrane and is expressed highly during vitellogenesis during the time that the oocyte grows dramatically in size [165]. An additional target of miR-101 is the high choriolytic enzyme or hatching enzyme 2 (he2), which is required for egg envelope digestion and is expressed during late stage ovarian development $[165,171]$. Choriolysins also are expressed during ovarian atresia and related to poor egg quality as discussed below. Some miRNAs that were differentially expressed in rainbow trout eggs, such as miR-449 and miR-203, also have been linked to cell death and tumor suppression $[72,172,173]$.

Various methods are now available to perform quantitative mass spectrometry with good resolution even of complex mixtures such as egg yolk or ovarian tissue homogenates $[154,174,175]$. One requirement for protein identification is a reference transcriptome or genome (see: $[175,176])$. Yilmaz et al. found that good and poor-quality zebrafish (Danio rerio) eggs have distinct proteomic profiles [86]. Low quality zebrafish eggs were found to be deficient in proteins related to protein synthesis, energy and lipid metabolism, and some vitellogenin products and lectins [86]. The 
importance of vitellogenins were similarly observed in Eurasian perch [174]. Furthermore, low quality zebrafish eggs were found to have a higher frequency of up-regulated zona pellucida (egg envelope) proteins and proteins involved in endo-lysosomal activities, autophagy, apoptosis, and some oncogene products [86]. The up-regulation of proteins related to endosome and lysosome activity suggests that the transition of oocytes to final maturation may be compromised and this may involve proteolysis of vitellogenin-derived yolk [86]. Similarly, the increased up-regulation of proteins related to oncogene functions may be representative of attempts to offset apoptosis, which may occur during ovarian aresia that may accompany broodstock stress [86]. Two ribosomal proteins were unique to good quality zebrafish eggs (rpl36-001 and rpl36-002) and four proteins were unique to poor quality eggs (tubulin zgc:55461-001, carbonyl reductase cbr1-001, casein kinase zgc:86598-001, and $2^{\prime}, 3^{\prime}$-cyclic nucleotide $3^{\prime}$ phosphodiesterase cnp-201). Additionally, three isoforms of c-reactive protein 3 (Crp3), three isoforms of profilin-family member 2-like (Pfn2l), four fish egg lectin-like proteins, one form of phosphoglucomutase 1 (Pgm1), and a variant of deoxyuridine $5^{\prime}$-triphosphate nucleotide-hydrolase (Dut-004) were found to be up-regulated in zebrafish eggs of good quality and four forms of ADP-ribosylation factor (Arf) and one form of ribosomal protein L22 (Rpl22) were found to be significantly up-regulated in poor quality eggs. Castets et al. reported that heat shock proteins, in particular members of the HSP70 family, were significantly up-regulated in the ovulated eggs of Eurasian perch that produced high fertility spawns [174]. Additionally, Prx2, Prx5, Prx6, and transferrin were found to be down-regulated in poor quality Eurasian perch eggs, suggesting that oxidative stress also may be an important factor that influences egg quality. These protein factors, thus also may serve as indicators of egg quality.

\section{Stress and Ovarian Atresia}

It is well known that stress negatively affects reproductive performance of fishes including, but not limited to, poor water quality, osmoregulatory challenge, crowding, starvation, disease, handling, and tank confinement [59]. The primary stress hormones, adrenaline and principally cortisol, suppress the reproductive hormone axis. The influence of stress on reproductive output is ultimately attributed to inhibition of reproductive hormones (GnRH, FSH, LH and others) [59-61]. The influence of cortisol on reproductive hormones is varied among species and it is difficult to pinpoint what aspects of reproductive performance are directly influenced by cortisol or any other stress-coping mechanisms. High rearing density increases the expression of some stress-related genes in European sea bass, although the reproductive performance of these animals was not tested [61]. However, acute stress also has been shown to generally inhibit steroidogenesis in the fish gonad [63] and reduces egg quality in rainbow trout [64] and other fishes [65]. Increases in plasma cortisol and adrenocorticotropin hormone (ACTH) after acute stress, chronic confinement, and high population density has been found to reduce plasma testosterone, 11-ketotestosterone (11KT), and E2 levels in broodstock [48]. Reduction of gonadal steroid production due to the stress response also has been shown to reduce female fecundity [66]. During ovarian maturation, reduction of progesterone synthesis due to stress, such as over handling of broodstock, may inhibit ovulation and result in complete reproductive failure.

The stress response also mobilizes energy stores that are required to combat the insult or noxious stressor [67] and this action may result in redistribution of bioenergetic resources away from gonad growth during the periods of previtellogenesis (oocyte lipidation) and vitellogenesis (yolk deposition), as examples. Thus, stress during the time when essential nutrients are being deposited into the oocyte may result in eggs that are not appropriately yolked as the bioenergetic demand to grow eggs is high and this may be offset to other processes during stress [48]. Energy depletion caused by mitigating the effects of stress may also impact active reproductive behaviors including nest formation, courtship, and migration activities [48]. The effects of stress on the deposition of maternal gene transcripts or epigenetic programming of the oocyte are generally unknown in fishes and very few studies have been conducted on this. Le Luyer et al. found differentially methylated regions in the genome between hatchery-reared and wild caught coho salmon (Oncorhynchus kisutch), however, the physiological 
impacts of these epigenetic differences are unclear [68]. Therefore all attempts at husbandry of fish broodstock should aim to mitigate or limit any known stressors in order to provide an environment conducive to promoting the highest quality eggs.

In exceptionally sensitive fish species held in captivity, cases of extreme duress [59], or when gravid female broodstock are held past their prime without spawning [52], the onset of ovarian atresia may occur. Ovarian atresia also may occur due improper environmental conditioning cues for spawning $[58,69]$. Atresia is a process whereby the female fish will abort the spawning cycle and begin to reabsorb the eggs to recycle the yolk nutrients. Indicators of ovarian atresia include the appearance of edema in the granulosa cell layer of the follicle observed from ovarian tissue biopsies and this may accompany apotosis of cells in the ovary [52]. In later stages, atresia may result in eggs rupturing or disintegrating upon gentle handling as one of the mechanisms involved in oocyte reabsorption includes the production of choriolysin enzymes, which break down the chorion [70]. In most cases, females which undergo ovarian atresia will produce low quality eggs or deformed embryos and in extreme some cases no fertility. Atresia can be delayed for weeks or months in some temperate fish species by holding gravid females at temperatures lower than the typical spawning temperature in a process called "cold banking" [52], however this is not an indeterminate period. Avoiding ovarian atresia requires husbandry practices that eliminate stressors and an understanding of the reproductive cycle in order to properly time captive spawning.

\section{Postovulatory Aging}

Postovulatory aging (also called over-ripening) can be considered one of the most important factors affecting egg quality, particularly in cultured species that do not volitionally oviposit ovulated eggs and require manual strip spawning [73-76]. For some species, such as striped bass, over-ripening can result in complete infertility in as little as 15 to $30 \mathrm{~min}$ post-ovulation. The problem of postovulatory aging occurs due to the ovulation event, whereby the oocyte is released as an egg from the ovarian follicle and thereby is removed from the maternal blood supply that provides nourishment and oxygen. Thus, special attention must be paid to accurate prediction of ovulation and the appropriate time for manual stripping of eggs. In an attempt to avoid over-ripening, female fish may be frequently examined during the spawning time, however it requires technical expertise to differentiate viable eggs from nonviable eggs especially in species such as rainbow trout [73] or striped bass [95]. Furthermore, handling of broodstock to make such evaluations requires experienced personnel and can cause stress to the breeding fish, which may further negatively impact the quality of eggs as stress hormones, such as adrenaline and cortisol, may suppress $\mathrm{GnRH}$ and other downstream reproductive hormones required for ovulation.

Salmonids have served as a template for understanding postovulatory aging and extensive research has been conducted on rainbow trout, Atlantic salmon (Salmo salar) and related species as they ovulate their eggs into the body cavity and can retain them viably for a considerable amount of time (6-10 days) [73]. For example, Mommens et al. found that postovulatory aging significantly decreased fertilization rate, embryo, alevin, and juvenile survival rates, and increased the presence of deformities in alevin and juvenile Atlantic salmon [77]. Coelomic fluid $\mathrm{pH}$ was also found to be an indicator of postovulatory aging in Atlantic salmon, presenting the need of standardized measurements for the identification of low-quality oocytes to improve production [77]. The same $\mathrm{pH}$ indicator of postovulatory aging was also found in rainbow trout coelomic fluid, which additionally included an increased level of fatty acids and proteins, and aspartate aminotransferase and acid phosphatase [75,77-79]. Hajirezaee et al. performed a metabolomic evaluation of postovulatory aging in rainbow trout, which included measurements of amino acids, osmolytes, and energy metabolites in ovarian fluid during the in vitro storage of ova [80]. These authors postulated that an observed increase in creatine in the ovarian fluid may be linked to egg damage yielding a leakage of the metabolite. Hajirezaee et al. also notes that an observed increase in reactive oxygen species (ROS) is correlated to egg over-ripening, which also may be related to the decrease over time of osmolytes 
that serve as antioxidants [80]. Rainbow trout eggs subjected to postovulatory aging also have lower mRNA expression of $n p m 2$, tubulin b, igf1, igf2 and higher expression of keratins 8 (krt8) and $18(\mathrm{krt} 8)$, cathepsin Z (ctsz), and prostaglandin synthase 2 [48,72]. The gene npm2 is a histone chaperone critical to embryonic development in mice and Brazert and Pawelczyk demonstrated a link between igf1 and folliculogenesis and ovarian dysfunction in humans [81,82]. Tubulin $b$ is a component of the cytoskeleton and thus is involved in cell division, the importance of which is aforementioned.

The mitochondrion has also been found to play a significant role in epigenetic regulation such as apoptosis, in addition to ATP generation and cell homeostasis important to eggs $[71,72,76,83,84]$. In an analysis of mitochondrial genome-encoded small RNA (mitosRNAs) in rainbow trout, Ma et al. (2016) found ninety-eight mitosRNAs expressed in eggs that differed greater than three-fold with postovulatory age and associated fertilization rate [76]. Like miRNAs, mitosRNAs function in RNA silencing and post-transcriptional regulation of gene expression, however within the mitochondria [84]. Ma et al. suggested that further characterization of these mitosRNAs may allow for identification of egg quality biomarkers for rainbow trout and other similar species related to mitochondrial dysfunction that may accompany overripening [76]. Two important mitosRNAs that were identified in trout are omy-miR-nov-95-5p and omy-miR-193b-5p. The omy-miR-nov-95-5p is a novel mitosRNA that targets cox6b1, a gene that if down-regulated in eggs overtime, may affect mitochondrial respiration and egg quality. Other genes identified as targets of both omy-miR-95-5p and omy-miR-193b-5p have been linked to cell death, stress response, DNA repair, and DNA and RNA damage, including rassf5, $r p b 4, r e c q 4 a, c h d 1 l, w d r 61$, and cnot1 [72]. Lord and Aitken suggest that oxidative stress may be what triggers mitochondrial dysfunction in mice, but further research is necessary to pinpoint the induction of negative effects of the mitochondrion on postovulatory aging in fish eggs [85]. Further research and technology development centered around determining egg viability and biomarkers for egg quality especially in regard to postovulatory aging is required for the improvement of spawning in culture systems of a variety of species.

\section{Future Research Directions}

It is imperative to understand the mechanisms of high egg quality for broodstock management, especially as changes in the environment and demand for animal-based protein shifts more towards aquaculture. There is a need to focus on understanding and mitigating the effects of handling and other stressors on broodstock, informative spawning protocols for broodstock conditioning including nutritional requirements, spawning induction, and identification of postovulatory aging and atresia. The need to identify such effects and possible ways to mitigate each may prove to be very influential to egg quality and continued success of the aquaculture industry. Further investigation of the intracellular components of good egg quality through the study of omics is critical to establishing a full picture of what factors contribute overall to egg quality and therefore what management and production practices are most important in establishing, maintaining, and improving spawning protocols for all cultured fish species. Examining handling stress can easily build upon findings of present egg quality studies such as metabolomic pathways and indicators of poor quality eggs, especially in regard to postovulatory aging. Understanding the maternal RNA contribution during oogenesis and embryogenesis as well as when genes are masked and unmasked during development is not only critical for providing insight to the contributing factors of high and low quality eggs, but can also influence broodstock selection to identify optimal spawning fish through the use of markers for egg quality.

Author Contributions: Conceptualization, B.J.R., N.H., and L.K.A.; Writing-original draft preparation and literature review, B.J.R., L.K.A., Y.M., Y.W.R., and T.T.; Writing-Review \& Editing, B.J.R., L.K.A., Y.M., Y.W.R., T.T., and N.H.; Visualization, B.J.R., Y.M., Y.W.R., L.K.A., and N.H.; Project Administration, B.J.R.; Funding Acquisition, B.J.R. All authors read and approved the final version of the manuscript. B.J.R., N.H., and T.T. have contributed seminal research to the study of oogenesis in fishes, principally on oocyte lipidation, vitellogenesis, and egg yolk formation and processing, studies of which are summarized in those sections. 
Funding: Funding for this research was provided to B.J.R. by the United States Department of Agriculture (USDA) National Research Support Project 8 (NRSP-8; National Animal Genome Project; USDA 0018889) and Northeastern Regional Aquaculture Center (USDA 14-078), Foundation for Food and Agriculture Research New Innovator Award (FFAR), North Carolina Division of Marine Fisheries (NC DMF 2017-F-046), North Carolina State University Agricultural Foundation and William White Endowment, North Carolina SeaGrant (R/12-SSS-3 and R/MG-1411), Nelson Wert and the Pennsylvania Striped Bass Association, and other benefactors including those from government agencies, non-profit organizations, companies, and owner-operator aquaculture producers. B.J.R. is a member of the NRSP-8 and Co-Coordinator of the National Program for Genetic Improvement and Selective Breeding for the Hybrid Striped Bass Industry. This is publication number 116 from the North Carolina State University Pamlico Aquaculture Field Laboratory.

Acknowledgments: The authors thank Andrew S. McGinty, Michael S. Hopper, and Robert W. Clark for their longstanding contributions to the National Program for Genetic Improvement and Selective Breeding for the Hybrid Striped Bass Industry.

Conflicts of Interest: All authors declare that there is no conflict of interest in this work.

\section{References}

1. Bobe, J.; Labbé, C. Egg and sperm quality in fish. Gen. Comp. Endocrinol. 2009, 165, 535-548. [CrossRef] [PubMed]

2. Chapman, R.W.; Reading, B.J.; Sullivan, C.V. Ovary transcriptome profiling via artificial intelligence reveals a transcriptomic fingerprint predicting egg quality in striped bass, Morone saxatilis. PLoS ONE 2014, 9, e96818. [CrossRef] [PubMed]

3. Bobe, J. Egg quality in fish: Present and future challenges. Anim. Front. 2015, 5, 66-72. [CrossRef]

4. Sullivan, C.V.; Chapman, R.W.; Reading, B.J.; Anderson, P.E. Transcriptomics of mRNA and egg quality in farmed fish: Some recent developments and future directions. Gen. Comp. Endocrinol. 2015, 221, 23-30. [CrossRef] [PubMed]

5. Endo, T.; Todo, T.; Lokman, P.M.; Kudo, H.; Ijiri, S.; Adachi, S.; Yamauchi, K. Androgens and very low density lipoprotein are essential for the growth of previtellogenic oocytes from Japanese eel, Anguilla japonica, in vitro. Biol. Reprod. 2011, 84, 816-825. [CrossRef] [PubMed]

6. Damsteegt, E.L.; Mizuta, H.; Hiramatsu, N.; Lokman, P.M. How does eggs get fats? Insights into ovarian fatty acid accumulation in the shortfinned eel, Anguilla australis. Gen. Comp. Endocrinol. 2015, 221, 94-100. [CrossRef] [PubMed]

7. Hiramatsu, N.; Todo, T.; Sullivan, C.V.; Schilling, J.; Reading, B.J.; Matsubara, T.; Ryu, Y.W.; Mizuta, H.; Luo, W.; Nishimiya, O.; et al. Ovarian yolk formation in fishes: Molecular mechanisms underlying formation of lipid droplets and vitellogenin-derived yolk proteins. Gen. Comp. Endocrinol. 2015, 221, 9-15. [CrossRef] [PubMed]

8. Lubzens, E.; Bobe, J.; Young, G.; Sullivan, C.V. Maternal investment in fish oocytes and eggs: The molecular cargo and its contributions to fertility and early development. Aquaculture 2017, 472, 107-143. [CrossRef]

9. Ibáñez, A.J.; Peinado-Insurbe, J.; Sánchez, E.; Cerdá-Reverter, J.M.; Prat, F. Lipoprotein lipase (LPL) is highly expressed and active in the ovary of European sea bass (Dicentrarchus labrax L.), during gonadal development. Comp. Biochem. Physiol. A 2008, 150, 347-354. [CrossRef] [PubMed]

10. Ryu, Y.-W.; Tanaka, R.; Kasahara, A.; Ito, Y.; Hiramatsu, N.; Todo, T.; Sullivan, C.V.; Hara, A. Molecular cloning and transcript expression of genes encoding two types of lipoprotein lipase in the ovary of cutthroat trout, Oncorhynchus clarkii. Zool. Sci. 2013, 30, 224-237. [CrossRef] [PubMed]

11. Mushirobira, Y.; Nishimiya, O.; Nagata, J.; Todo, T.; Hara, A.; Reading, B.J.; Hiramatsu, N. Molecular cloning of vitellogenin gene promoters and in vitro and in vivo transcription profiles following estradiol-17 $\beta$ administration in the cutthroat trout. Gen. Comp. Endocrinol. 2018, 267, 157-166. [CrossRef] [PubMed]

12. Davis, L.K.; Hiramatsu, N.; Hiramatsu, K.; Reading, B.J.; Matsubara, T.; Hara, A.; Sullivan, C.V.; Pierce, A.L.; Hirano, T.; Grau, E.G. Induction of three vitellogenins by $17 \beta$-estradiol with concurrent inhibition of the growth hormone-insulin-like growth factor 1 axis in a euryhaline teleost, the tilapia (Oreochromis mossambicus). Biol. Reprod. 2007, 77, 614-625. [CrossRef] [PubMed]

13. Reading, B.J.; Hiramatsu, N.; Sullivan, C.V. Disparate binding of three types of vitellogenin to multiple forms of vitellogenin receptor in white perch. Biol. Reprod. 2011, 84, 392-399. [CrossRef] [PubMed] 
14. Reading, B.J.; Hiramatsu, N.; Schilling, J.; Molloy, K.T.; Glassbrook, N.; Mizuta, H.; Luo, W. Lrp13 is a novel vertebrate lipoprotein receptor that binds vitellogenins in teleost fishes. J. Lipid Res. 2014, 55, 2287-2295. [CrossRef] [PubMed]

15. Reading, B.J.; Sullivan, C.V.; Schilling, J. Vitellogenesis in Fishes. In Reference Module in Life Sciences; Elsevier: Amsterdam, The Netherlands, 2017.

16. Davail, B.; Pakdel, F.; Bujo, H.; Perazzolo, L.M.; Waclawek, M.; Schneider, W.J.; Le Menn, F. Evolution of oogenesis: The receptor for vitellogenin from the rainbow trout. J. Lipid Res. 1998, 39, 1929-1937. [PubMed]

17. Prat, F.; Coward, K.; Sumpter, J.P.; Tyler, C.R. Molecular characterization and expression of two ovarian lipoprotein receptors in the rainbow trout, Oncorhynchus mykiss. Biol. Reprod. 1998, 58, 1146-1153. [CrossRef] [PubMed]

18. Hiramatsu, N.; Chapman, R.W.; Lindzey, J.K.; Haynes, M.R.; Sullivan, C.V. Molecular characterization and expression of vitellogenin receptor from white perch (Morone americana). Biol. Reprod. 2004, 70, 1720-1730. [CrossRef] [PubMed]

19. Mizuta, H.; Luo, W.; Ito, Y.; Mushirobira, Y.; Todo, T.; Hara, A.; Reading, B.J.; Sullivan, C.V.; Hiramatsu, N. Ovarian expression and localization of vitellogenin receptor with eight ligand binding repeats in the cutthroat trout (Oncorhynchus clarkii). Comp. Biochem. Physiol. Part B 2013, 166, 81-90. [CrossRef] [PubMed]

20. Mushirobira, Y.; Mizuta, H.; Luo, W.; Todo, T.; Hara, A.; Reading, B.J.; Sullivan, C.V.; Hiramatsu, N. Molecular cloning and partial characterization of a low-density lipoprotein receptor-related protein 13 (Lrp13) involved in vitellogenin uptake in the cutthroat trout (Oncorhynchus clarkii). Mol. Reprod. Dev. 2015, 82, 986-1000. [CrossRef] [PubMed]

21. Mizuta, H.; Mushirobira, Y.; Nagata, J.; Todo, T.; Hara, A.; Reading, B.J.; Sullivan, C.V.; Hiramatsu, N. Ovarian expression and localization of clathrin (Cltc) components in cutthroat trout, Oncorhynchus clarkii: Evidence for Cltc involvement in endocytosis of vitellogenin during oocyte growth. Comp. Biochem. Physiol. A Mol. Integr. Physiol. 2017, 212, 24-34. [CrossRef] [PubMed]

22. Hiramatsu, N.; Ichikawa, N.; Fukada, H.; Fujita, T.; Sullivan, C.V.; Hara, A. Identification and characterization of proteases involved in specific proteolysis of vitellogenin and yolk proteins in salmonids. J. Exp. Zool. 2002, 292, 11-25. [CrossRef] [PubMed]

23. Carnevali, O.; Centonze, F.; Brooks, S.; Marota, I.; Sumpter, J.P. Molecular cloning and expression of ovarian cathepsin D in seabream, Sparus aurata. Biol. Reprod. 1999, 61, 785-791. [CrossRef] [PubMed]

24. Finn, R.N. Vertebrate Yolk Complexes and the Functional Implications of Phosvitins and Other Subdomains in Vitellogenins. Biol. Reprod. 2007, 76, 926-935. [CrossRef] [PubMed]

25. Reading, B.J.; Sullivan, C.V. Vitellogenesis in fishes. In Encyclopedia of Fish Physiology; Farrell, A.P., Cech, J.J., Richard, J.G., Stevens, E.D., Eds.; Academic Press: San Diego, CA, USA, 2011.

26. Matsubara, T.; Ohkubo, N.; Andoh, T.; Sullivan, C.V.; Hara, A. Two forms of vitellogenin, yielding two distinct lipovitellins, play different roles during oocyte maturation and early development of barfin flounder, Verasper moseri, a marine teleost that spawns pelagic eggs. Dev. Biol. 1999, 213, 18-32. [CrossRef] [PubMed]

27. Sawaguchi, S.; Ohkubo, N.; Amano, H.; Hiramatsu, N.; Hara, A.; Sullivan, C.V.; Matsubara, T. Controlled accumulation of multiple vitellogenins into oocytes during vitellogenesis in the barfin flounder, Varasper moseri. Cybium 2008, 32, 262.

28. Williams, V.N.; Reading, B.J.; Amano, H.; Hiramatsu, N.; Schilling, J.; Salger, S.A.; Williams, T.I.; Gross, K.; Sullivan, C.V. Proportional accumulation of yolk proteins derived from multiple vitellogenins is precisely regulated during vitellogenesis in striped bass (Morone saxatilis). J. Exp. Zool. Part A 2014, 321, 301-315. [CrossRef] [PubMed]

29. Schilling, J.; Loziuk, P.L.; Muddiman, D.C.; Daniels, H.V.; Reading, B.J. Mechanisms of Egg Yolk Formation and Implications on Early Life History of White Perch (Morone americana). PLoS ONE 2015, 10, e0143225. [CrossRef] [PubMed]

30. Sawaguchi, S.; Koya, Y.; Yoshizaki, N.; Ohkubo, N.; Andoh, T.; Hiramatsu, N.; Sullivan, C.V.; Hara, A.; Matsubara, T. Multiple vitellogenins (Vgs) in mosquitofish (Gambusia affinis): Identification and characterization of three functional Vg genes and their circulating and yolk protein products. Biol. Reprod. 2005, 72, 1045-1060. [CrossRef] [PubMed] 
31. Sawaguchi, S.; Kagawa, H.; Ohkubo, N.; Hiramatsu, N.; Sullivan, C.V.; Matsubara, T. Molecular characterization of three forms of vitellogenin and their yolk protein products during oocyte growth and maturation in red seabream (Pagrus major), a marine teleost spawning pelagic eggs. Mol. Reprod. Dev. 2006, 73, 719-736. [CrossRef] [PubMed]

32. Reith, M.; Munholland, J.; Kelly, J.; Finn, R.N.; Fyhn, H.J. Lipovitellins derived from two forms of vitellogenin are differentially processed during oocyte maturation in haddock (Melanogrammus aeglefinus). J. Exp. Zool. 2001, 291, 58-67. [CrossRef] [PubMed]

33. Finn, R.N. The Maturational Disassembly and Differential Proteolysis of Paralogous Vitellogenins in a Marine Pelagophil Teleost: A Conserved Mechanism of Oocyte Hydration. Biol. Reprod. 2007, 76, 936-948. [CrossRef] [PubMed]

34. Yilmaz, O.; Patinote, A.; Nguyen, T.; Bobe, J. Multiple vitellogenins in zebrafish (Danio rerio): Quantitative inventory of genes, transcripts and proteins, and relation to egg quality. Fish Physiol. Biochem. 2018, 1-17. [CrossRef] [PubMed]

35. Matsubara, T.; Koya, Y. Course of proteolytic cleavage in three classes of yolk proteins during oocyte maturation in barfin flounder Verasper moseri, a marine teleost spawning pelagic eggs. J. Exp. Zool. 1997, 278, 189-200. [CrossRef]

36. Carnevali, O.; Cionna, C.; Tosti, L.; Cerdà, J.; Gioacchini, G. Changes in cathepsin gene expression and relative enzymatic activity during gilthead sea bream oogenesis. Mol. Reprod. Dev. 2008, 75, 97-104. [CrossRef] [PubMed]

37. Carnevali, O.; Carletta, R.; Cambi, A.; Vita, A.; Bromage, N. Yolk formation and degradation during oocyte maturation in seabream Sparus aurata: Involvement of two lysosomal proteinases. Biol. Reprod. 1999, 60, 140-146. [CrossRef] [PubMed]

38. Carnevali, O.; Mosconi, G.; Cardinali, M.; Meiri, I.; Polzonetti-Magni, A. Molecular components related to egg viability in the gilthead sea bream, Sparus aurata. Mol. Reprod. Dev. Incorp. Gamete Res. 2001, 58, 330-335. [CrossRef]

39. Gwon, S.H.; Kim, H.K.; Baek, H.J.; Lee, Y.D.; Kwon, J.Y. Cathepsin B and D and the Survival of Early Embryos in Red Spotted Grouper, Ephinephelus akaara. Dev. Reprod. 2017, 21, 457-466. [CrossRef] [PubMed]

40. Cerdà, J. Molecular pathways during marine fish egg hydration: The role of aquaporins. J. Fish Biol. 2009, 75, 2175-2196. [CrossRef] [PubMed]

41. Chauvigné, C.; Zapater, C.; Cerdà, J. Role of aquaporins during teleost gametogenesis and early embryogenesis. Front. Physiol. 2011, 2, 66. [CrossRef] [PubMed]

42. Żarski, D.; Nguyen, T.; Le Cam, A.; Montfort, J.; Dutto, G.; Odile Vidal, M.; Fauvel, C.; Bobe, J. Transcriptomic profiling of egg quality in sea bass (Dicentrarchus labrax) sheds light on genes involved in ubiquitination and translation. Mar. Biotechnol. 2017, 19, 102-115. [CrossRef] [PubMed]

43. Aegerter, S.; Jalabert, B.; Bobe, J. Messenger RNA stockpile of cyclin B, insulinlike growth factor I, insulin-like growth factor II, insulin-like growth factor receptor $\mathrm{Ib}$, and $\mathrm{p} 53$ in the rainbow trout oocyte in relation with developmental competence. Mol. Reprod. Dev. 2004, 67, 127-135. [CrossRef] [PubMed]

44. Mathavan, S.; Serene, G.P.L.; Alicia, M.; Lance, D.M.; Karuturi, R.K.M.; Kunde, R.; Govindarajan, Y.T.; Wu, Y.L.; Lam, S.H.; Yang, H.; et al. Transcriptome analysis of zebrafish embryogenesis using microarrays. PLoS Genet. 2005, 1, e29. [CrossRef] [PubMed]

45. Fernández, C.G.; Roufidou, C.; Antonopoulou, E.; Sarropoulou, E. Expression of developmental-stage-specific genes in the gilthead sea bream Sparus aurata L. Mar. Biotechnol. 2013, 15, 313-320. [CrossRef] [PubMed]

46. Rise, M.L.; Nash, G.W.; Hall, J.R.; Booman, M.; Hori, T.S.; Trippel, E.A.; Gamperl, A.K. Variation in embryonic mortality and maternal transcript expression among Atlantic cod (Gadus morhua) broodstock: A functional genomics study. Mar. Genom. 2014, 18, 3-20. [CrossRef] [PubMed]

47. Bonnet, E.; Fostier, A.; Bobe, J. Microarray-based analysis of fish egg quality after natural or controlled ovulation. BMC Genom. 2007, 8, 55. [CrossRef] [PubMed]

48. Aegerter, S.; Jalabert, B.; Bobe, J. Large scale real-time PCR analysis of mRNA abundance in rainbow trout eggs in relationship with egg quality and post-ovulatory ageing. Mol. Reprod. Dev. Incorp. Gamete Res. 2005, 72, 377-385. [CrossRef] [PubMed]

49. Mommens, M.; Fernandes, J.M.O.; Tollefsen, K.E.; Johnston, I.A.; Babiak, I. Profiling of the embryonic Atlantic halibut (Hippoglossus hippoglossus L.) transcriptome reveals maternal transcripts as potential markers of embryo quality. BMC Genom. 2014, 15, 829. [CrossRef] [PubMed] 
50. Lanes, C.F.C.; Fernandes, J.M.O.; Babiak, K.I. Profiling of key apoptotic, stress, and immune-related transcripts during embryonic and postembryonic development of Atlantic cod (Gadus morhua L.). Theriogenology 2012, 78, 1583-1596. [CrossRef] [PubMed]

51. Mommens, M.; Fernandes, J.M.O.; Bizuayehu, T.T.; Bolla, S.L.; Johnston, I.A.; Babiak, I. Maternal gene expression in Atlantic halibut (Hippoglossus hippoglossus L.) and its relation to egg quality. BMC Res. Notes 2010, 3, 138. [CrossRef] [PubMed]

52. Sullivan, C.V.; Hiramatsu, N.; Kennedy, A.M.; Clark, R.W.; Weber, G.M.; Matsubara, T.; Hara, A. Induced maturation and spawning: Opportunities and applications for research on oogenesis. Fish Physiol. Biochem. 2003, 28, 481-486. [CrossRef]

53. Patiño, R.; Sullivan, C.V. Ovarian follicle growth, maturation, and ovulation in teleost fish. Fish Physiol. Biochem. 2002, 26, 57-70. [CrossRef]

54. Reading, B.J.; Hiramatsu, N.; Sawaguchi, S.; Matsubara, T.; Hara, A.; Lively, M.O.; Sullivan, C.V. Conserved and variant molecular and functional features of multiple egg yolk precursor proteins (vitellogenins) in white perch (Morone americana) and other teleosts. Mar. Biotechnol 2009, 11, 169-187. [CrossRef] [PubMed]

55. Amano, H.; Fujita, T.; Hiramatsu, N.; Shimizu, M.; Sawaguchi, S.; Matsubara, T.; Kagawa, H.; Nagae, M.; Sullivan, C.V.; Hara, A. Egg yolk proteins in grey mullet (Mugil cephalus): Purification and classification of multiple lipovitellins and other vitellogenin-derived yolk proteins and molecular cloning of the parent vitellogenin genes. J. Exp. Zool. Part A 2007, 307, 324-341. [CrossRef] [PubMed]

56. Patiño, R.; Thomas, P. Induction of maturation of Atlantic croaker oocytes by $17 \alpha, 20 \beta, 21$-trihydroxy-4pregnen-3-one in vitro: Consideration of some biological and experimental variables. J. Exp. Zool. 1990, 255, 97-109. [CrossRef] [PubMed]

57. Matsubara, T.; Sawano, K. Proteolytic cleavage of vitellogenin and yolk proteins during vitellogenin uptake and oocyte maturation in barfin flounder (Verasper moseri). J. Exp. Zool. 1995, 272, 34-45. [CrossRef]

58. Zohar, Y.; Mylonas, C.C. Endocrine manipulations of spawning in cultured fish: From hormones to genes. Reprod. Biotechnol. Finfish Aquac. 2001, 197, 99-136.

59. Tort, L. Impact of stress in health and reproduction. In Encyclopedia of Fish Physiology; Farrell, A.P., Cech, J.J., Richard, J.G., Stevens, E.D., Eds.; Academic Press: San Diego, CA, USA, 2011.

60. Milla, S.; Wang, N.; Mandiki, S.N.M.; Kestemont, P. Corticosteroids: Friends or foes of teleost fish reproduction? Comp. Biochem. Physiol. A 2009, 153, 242-251. [CrossRef] [PubMed]

61. Wendelaar Bonga, S.E. Hormonal responses to stress: Hormone response to stress. In Encyclopedia of Fish Physiology; Academic Press: San Diego, CA, USA, 2011; pp. 1515-1523.

62. Gornati, R.; Papis, E.; Rimoldi, S.; Terova, G.; Saroglia, M.; Bernardini, G. Rearing density influences the expression of stress-related genes in sea bass (Dicentrarchus labrax, L.). Gene 2004, 341, 111-118. [CrossRef] [PubMed]

63. Pankhurst, N.W.; Van Der Kraak, G. Evidence that acute stress inhibits ovarian steroidogenesis in rainbow trout in vivo, through the action of cortisol. Gen. Comp. Endocrinol. 2000, 117, 225-237. [CrossRef] [PubMed]

64. Campbell, P.M.; Pottinger, T.G.; Sumpter, J.P. Stress reduces the quality of gametes produced by rainbow trout. Biol. Reprod. 1992, 47, 1140-1150. [CrossRef] [PubMed]

65. Schreck, C.B.; Contreras-Sanchez, W.; Fitzpatrick, M.S. Effects of stress on fish reproduction, gamete quality, and progeny. Reprod. Biotechnol. Finfish Aquac. 2001, 3-24. [CrossRef]

66. Schreck, C.B. Stress and fish reproduction: The roles of allostasis and hormesis. Gen. Comp. Endocrinol. 2010, 165, 549-556. [CrossRef] [PubMed]

67. Baltzegar, D.A.; Reading, B.J.; Douros, J.D.; Borski, R.J. Role for leptin in promoting glucose mobilization during acute hyperosmotic stress in teleost fishes. J. Endocrinol. 2013, 220, 61-72. [CrossRef] [PubMed]

68. Le Luyer, J.; Laporte, M.; Beacham, T.D.; Kaukinen, K.H.; Withler, R.E.; Leong, J.S.; Rondeau, E.B.; Koop, B.F.; Bernatchez, L. Parallel epigenetic modifications induced by hatchery rearing in a Pacific salmon. Proc. Natl. Acad. Sci. USA 2017, 114, 12964-12969. [CrossRef] [PubMed]

69. Meiri, I.; Gothilf, Y.; Zohar, Y.; Elizur, A. Physiological changes in the spawning gilthead seabream, Sparus aurata, succeeding the removal of males. J. Exp. Zool. 2002, 292, 555-564. [CrossRef] [PubMed]

70. Donato, D.M.; Hiramatsu, N.; Arey, K.M.; Hiramatsu, K.; Kennedy, A.M.; Morton, C.L.; Hara, A.; Sullivan, C.V. Atresia in temperate basses: Cloning of hatching enzyme (choriolysin) homologues from atretic ovaries. Fish Physiol. Biochem. 2003, 28, 329-330. [CrossRef] 
71. Ma, H.; Hostuttler, M.; Wei, H.; Rexroad, C.E., III; Yao, J. Characterization of the rainbow trout egg microRNA transcriptome. PLoS ONE 2012, 7, e39649. [CrossRef] [PubMed]

72. Ma, H.; Weber, G.M.; Hostuttler, M.A.; Wei, H.; Wang, L.; Yao, J. MicroRNA expression profiles from eggs of different qualities associated with post-ovulatory ageing in rainbow trout (Oncorhyncchus mykiss). BMC Genom. 2015, 16, 201. [CrossRef] [PubMed]

73. Craik, J.C.A.; Harvey, S.M. Egg quality in rainbow trout: The relation between egg viability, selected aspects of egg composition, and time of stripping. Aquaculture 1984, 40, 115-134. [CrossRef]

74. Springate, J.R.C.; Bromage, N.R.; Elliot, J.A.K.; Hudson, D.L. The timing of ovulation and stripping and their effects on the rate of fertilization and survival to eyeing, hatch, and swim-up in the rainbow-trout (Salmo-Gairdneri R.). Aquaculture 1984, 43, 313-322. [CrossRef]

75. Lahnsteiner, F. Morphological, physiological and biochemical parameters characterizing the over-ripening of rainbow trout eggs. Fish Physiol. Biochem. 2000, 23, 107-118. [CrossRef]

76. Ma, H.; Weber, G.M.; Wei, H.; Yao, J. Identification of mitochondrial genome-encoded small RNAs related to egg deterioration caused by post ovulatory aging in rainbow trout. Mar. Biotechnol. 2016, 18, 584-597. [CrossRef] [PubMed]

77. Mommens, M.; Storset, A.; Bibiak, I. Some quantitative indicators of postovulatory aging and its effect on larval and juvenile development of Atlantic salmon (Salmo salar). Theriogenology 2015, 84, 170-176. [CrossRef] [PubMed]

78. Aegerter, S.; Jalabert, B. Effects of post-ovulatory oocyte ageing and temperature on egg quality and on the occurrence of triploid fry in rainbow trout, Oncorhynchus mykiss. Aquaculture 2004, 231, 59-71. [CrossRef]

79. Rime, H.; Guitton, N.; Pineau, C.; Bonnet, E.; Bobe, J.; Jalabert, B. Post-ovulatory ageing and egg quality: A proteomic analysis of rainbow trout coelomic fluid. Reprod. Biol. Endocrinol. 2004, 2, 26-36. [CrossRef] [PubMed]

80. Hajirezaee, S.; Khara, H.; Abed-Elmdoust, A.; Rafieepour, A.; Rahimi, R. Effects of egg aging on the metabolites of ovarian fluid in rainbow trout, Oncorhynchus mykiss. Aquac. Res. 2017, 49, 104-110. [CrossRef]

81. Burns, K.H.; Viveiros, M.M.; Ren, Y.; Wang, P.; DeMayo, F.J.; Frail, D.E.; Eppig, J.J.; Matzuk, M.M. Roles of NPM2 in chromatin and nucleolar organization in oocytes and embryos. Science 2003, 300, 633-636. [CrossRef] [PubMed]

82. Brazert, M.; Pawelczyk, L.A. Insulin-like growth factor-1 isoforms in human ovary. Preliminary report on the expression of the IGF-1 gene in PCOS patients and healthy controls. Ginekol. Pol. 2015, 86, 890-895. [CrossRef] [PubMed]

83. Suen, D.F.; Norris, K.L.; Youle, R.J. Mitochondrial dynamics and apoptosis. Genes Dev. 2008, 22, 1577-1590. [CrossRef] [PubMed]

84. Chinnery, P.F.; Elliott, H.R.; Hudson, G.; Samuels, D.C.; Relton, C.L. Epigenetics, epidemiology and mitochondrial DNA diseases. Int. J. Epidemiol. 2012, 41, 177-187. [CrossRef] [PubMed]

85. Lord, T.; Aitken, R.J. Oxidative stress and ageing of the postovulatory oocyte. Reproduction 2013, 146, $217-227$. [CrossRef] [PubMed]

86. Yilmaz, O.; Patinote, A.; Nguyen, T.V.; Com, E.; Lavigne, R.; Pineau, C.; Sullivan, C.V.; Bobe, J. Scrambled eggs: Proteomic portraits and novel biomarkers of egg quality in zebrafish (Danio rerio). PLoS ONE 2017, 12, e0188084. [CrossRef] [PubMed]

87. Mylonas, C.C.; Zohar, Y. Use of GnRHa-delivery systems for the control of reproduction in fish. Rev. Fish Biol. Fish. 2000, 10, 463-491. [CrossRef]

88. Hodson, R.G.; Sullivan, C.V. Induced maturation and spawning of domestic and wild striped bass, Morone saxatilis (Walbaum), broodstock with implanted GnRH analogue and injected hCG. Aquac. Res. 1993, 24, 389-398. [CrossRef]

89. Weber, G.M.; Sullivan, C.V. Effects of Insulin-Like Growth Factor-I on In Vitro Final Oocyte Maturation and Ovarian Steroidogenesis in Striped Bass, Morone saxatilis. Biol. Reprod. 2000, 63, 1049-1057. [CrossRef] [PubMed]

90. Weber, G.M.; Sullivan, C.V. Insulin-Like Growth Factor-I Induces Oocyte Maturational Competence but Not Meiotic Resumption in White Bass (Morone chrysops) Follicles In Vitro: Evidence for Rapid Evolution of Insulin-Like Growth Factor Action. Biol. Reprod. 2005, 72, 1177-1186. [CrossRef] [PubMed] 
91. Schilling, J.; Nepomuceno, A.I.; Planchart, A.; Yoder, J.A.; Kelly, R.M.; Muddiman, D.C.; Daniels, H.; Hiramatsu, N.; Reading, B.J. Machine learning reveals sex-specific $17 \beta$-estradiol-responsive expression patterns in white perch (Morone americana) plasma proteins. Proteomics 2015, 15, 2678-2690. [CrossRef] [PubMed]

92. Yamamoto, K.; Yamauchi, K. Sexual maturation of Japanese eel and production of eel larvae in the aquarium. Nature 1974, 251, 220-222. [CrossRef] [PubMed]

93. Ganias, K. Thirty years of using the postovulatory follicles method: Overview, problems, and alternatives. Fish. Res. 2012, 117-118, 63-74. [CrossRef]

94. Wallace, R.A.; Selman, K. Cellular and dynamic aspects of oocyte growth in teleosts. Am. Zool. 1981, 21, 325-343. [CrossRef]

95. Bayless, J.D. Artificial Propagation and Hybridization of Striped Bass, Morone saxatilis (Walbaum); South Carolina Wildlife and Marine Resources Department: Columbia, SC, USA, 1972.

96. Moser, H.G. Seasonal histological changes in the gonads of Sebastodes paucispinus, an ovoviviparious teleost (Family Scorpaenidae). J. Morphol. 1967, 123, 329-353. [CrossRef] [PubMed]

97. Üçüncü, S.I.; Çakici, Ö. Atresia and apoptosis in preovulatory follicles in the ovary of Danio rerio (Zebrafish). Turk. J. Fish. Aquat. Sci. 2009, 9, 215-221. [CrossRef]

98. Mylonas, C.C.; Woods, L.C., III; Zohar, Y. Cyto-histological examination of post-vitellogenesis and final oocyte maturation in captive-reared striped bass. J. Fish Biol. 1997, 50, 44-49. [CrossRef]

99. Harrell, R.M.; Kerby, J.H.; Minton, R.V. (Eds.) Culture and Propagation of Striped Bass and Its Hybrids; American Fisheries Society: Bethesda, MD, USA, 1990.

100. Specker, J.L.; Sullivan, C.V. Vitellogenesis in fishes: Status and perspectives. In Perspectives in Comparative Endocrinology; Davey, K.G., Peter, R.E., Tobe, S.S., Eds.; National Research Council of Canada: Ottawa, ON, Canada, 1994; pp. 304-315.

101. Brooks, S.; Tyler, C.R.; Sumpter, J.P. Egg quality in fish: What makes a good egg? Rev. Fish Biol. Fish. 1997, 7, 287-416. [CrossRef]

102. Al-Hafdeh, Y.S. Effects of dietary protein on growth and body composition of Nile tilapia, Oreochromis niloticus L. Aquac. Res. 1999, 30, 385-393. [CrossRef]

103. Watanabe, T.; Takeuchi, T.; Saito, M.; Nishimura, K. Effect of low protein-high calorie or essential fatty acid deficiency diet on reproduction of rainbow trout. Nippon Suisan Gakkaishi 1984, 50, 1207-1215. [CrossRef]

104. Trushenski, J.T. Saturated lipid sources in feeds for sunshine bass: Alterations in production performance and tissue fatty acid composition. N. Am. J. Aquac. 2009, 71, 363-373. [CrossRef]

105. Fahy, E.; Subramaniam, S.; Brown, H.A.; Glass, C.K.; Merrill, A.H.; Murphy, R.C.; Raetz, C.R.H.; Russell, D.W.; Seyama, Y.; Shaw, W.; et al. A comprehensive classification system for lipids. J. Lipid Res. 2005, 46, 839-861. [CrossRef] [PubMed]

106. Leray, C.; Nonnote, G.; Roubaud, D.; Leger, C. Incidence of (n-3) essential fatty acid deficiency on trout reproductive processes. Reprod. Nutr. Dev. 1985, 25, 567-581. [CrossRef] [PubMed]

107. Izquierdo, M.S.; Fernández-Palacios, H.; Tacon, A.G.J. Effect of broodstock nutrition on reproductive performance of fish. Aquaculture 2001, 197, 25-42. [CrossRef]

108. Tuncer, H.; Harrell, R.M. Essential fatty acid nutrition of larval striped bass (Morone saxatilis) and palmetto bass (M. saxatilis x M. chrysops). Aquaculture 1992, 101, 105-121. [CrossRef]

109. Harrell, R.M.; Woods, L.C., III. Comparative fatty acid composition of eggs from domesticated and wild striped bass (Morone saxatilis). Aquaculture 1995, 133, 225-233. [CrossRef]

110. Takeuchi, T.; Watanabe, T. Effects of various polyunsaturated fatty acids on growth and fatty acid compositions of rainbow trout Salmo gairdneri, coho salmon Onchorhynchus kisutch, and chum salmon Onchorhynchus keta. Bull. Jpn. Soc. Sci. Fish 1982, 48, 1745-1752. [CrossRef]

111. Watanabe, T. Lipid nutrition in fish. Comp. Biochem. Physiol. B 1982, 73, 3-15. [CrossRef]

112. Carrillo, M.; Zanuy, S. Manipulación de la reproducción de los teleósteos y calidad de las puestas. In Proceedings of the Actas del V Congreso Nacional de Acuicultura, Sant Carles de la Rápita, Spain, 10-13 May 1995; pp. 1-9.

113. Valdebenito, I.I.; Gallegos, P.C.; Effer, B.R. Gamete quality in fish: Evaluation parameters and determining factors. Zygote 2015, 23, 177-197. [CrossRef] [PubMed] 
114. Fuller, A.S.; Rawles, S.D.; McEntire, M.E.; Bader, T.J.; Riche, M.; Beck, B.H.; Webster, C.D. White bass (Morone chrysops) preferentially retain n-3 PUFA in ova when fed prepared diets with varying FA content. Lipids 2017, 52, 823-836. [CrossRef] [PubMed]

115. Nevenzel, J.C. Occurrence, function and biosynthesis of wax esters in marine organisms. Lipids 1970, 5, 308-319. [CrossRef] [PubMed]

116. Eldridge, M.B.; Joseph, J.D.; Taberski, K.M.; Seaborn, G.T. Lipid and fatty acid composition of the endogenous energy sources of striped bass (Morone saxatilis) eggs. Lipids 1983, 18, 510-513. [CrossRef] [PubMed]

117. Watanabe, T.; Kiron, V. Broodstock management and nutritional approaches for quality offsprings in the Red Sea Bream. In Broodstock Management and Egg Larval Quality; Bromage, N.R., Roberts, R.J., Eds.; Blackwell Science: Oxford, UK, 1995.

118. Rainuzzo, J.R.; Reitan, K.I.; Olsen, Y. The significance of lipids at early stages of marine fish: A review. Aquaculture 1997, 155, 105-118. [CrossRef]

119. Terner, C. Studies of metabolism in embryonic development-I. The oxidative metabolism of unfertilized and embryonated trout ova. Comp. Biochem. Physiol. 1968, 24, 941-950. [CrossRef]

120. Kimata, M. Changes of chemical composition during early development in the red seabream Crysophys major (Temminck et Schelegel) egg and larva. J. Fac. Mar. Sci. Technol. Tokai Univ. 1983, 16, 213-223.

121. Kimata, M. Changes of chemical composition during early development of egg and larva in the half beak, Hemiramphus sajori (Temminck et Schelegel). Bull. Jpn. Soc. Sci. Fish 1982, 48, 1663-1671. [CrossRef]

122. Tocher, D.R.; Fraser, A.J.; Sargent, J.R.; Gamble, J.C. Lipid class composition during embryonic and early larval development in Atlantic herring (Clupea harengus L.). Lipids 1985, 20, 84-89. [CrossRef] [PubMed]

123. Palace, V.P.; Werner, J. Vitamins $\mathrm{A}$ and $\mathrm{E}$ in the maternal diet influence egg quality and early life stage development in fish: A review. Sci. Mar. 2006, 70, 41-57. [CrossRef]

124. Hemre, G.I.; Mangor-Jensen, A.; Lie, O. Broodstock nutrition in turbot (Scophthalmus maximus) effect of dietary vitamin E. FiskeriDir. Skr., Ser. Ernæring. 1994, 8, 21-29.

125. Craik, J.C.A. Egg quality and egg pigment content in salmonid fishes. Aquaculture 1985, 47, 61-88. [CrossRef]

126. Craik, J.C.A.; Harvey, S.M. Egg Quality in Atlantic Salmon; International Council for the Exploration of the Sea: Copenhagen, Denmark, 1986; F2.

127. Harris, L.E. Effects of a broodfish diet fortified with canthaxanthin on female fecundity and egg color. Aquaculture 1984, 43, 179-183. [CrossRef]

128. Torrissen, O.J. Pigmentation of salmonids-Effects of carotenoids in eggs and start feeding diet on survival and growth rate. Aquaculture 1984, 43, 185-193. [CrossRef]

129. Choubert, G.; Blanc, J.M. Muscle pigmentation changes during and after spanwing in male and female rainbow trout, Oncorhynchus mykiss, fed dietary carotenoids. Aquat. Living Resour. 1993, 6, 163-168. [CrossRef]

130. Torrissen, O.J.; Christiansen, R. Requirements on carotenoids in fish diets. J. Appl. Ichthyol. 1995, 11, $225-230$. [CrossRef]

131. Takeuchi, M.; Ishii, S.; Ogiso, T. Effect of dietary vitamin E on growth, vitamin E distribution, and mortalities of the fertilized eggs and fry in ayo, Plecoglossus altivelis. Bull. Tokai Reg. Fish. Res. Lab. 1981, 104, 111-122.

132. Selman, K.; Wallace, R.A. Cellular aspects of oocyte growth in teleosts. Zool. Sci. 1989, 6, 211-231.

133. Kwon, J.Y.; Prat, F.; Randall, C.; Tyler, C.R. Molecular characterization of putative yolk processing enzymes and their expression during oogenesis and embryogenesis in rainbow trout (Oncorhynchus mykiss). Biol. Reprod. 2001, 65, 1701-1709. [CrossRef] [PubMed]

134. Divers, S.L.; McQuillan, H.J.; Matsubara, H.; Todo, T.; Lokman, P.M. Effects of reproductive stage and 11-ketotestosterone on LPL mRNA levels in the ovary of the shortfinned eel. J. Lipid Res. 2010, 51, 3250-3258. [CrossRef] [PubMed]

135. Selman, K.; Wallace, R.A.; Sarka, A.; Qi, X. Stages of oocyte development in the zebrafish, Brachydanio rerio. J. Morphol. 1993, 218, 203-224. [CrossRef] [PubMed]

136. Levi, L.; Ziv, T.; Admon, A.; Levai-Sivan, B.; Lubzens, E. Insight into molecular pathways of retinal metabolism, associated with vitellogenesis in zebrafish. Am. J. Physiol. Endocrinol. Metab. 2012, 302, E626-E646. [CrossRef] [PubMed]

137. Clark, R.W.; Henderson-Arzapalo, A.; Sullivan, C.V. Disparate effects of constant and annually-cycling daylength and water temperature on reproductive maturation of striped bass (Morone saxatilis). Aquaculture 2005, 249, 497-513. [CrossRef] 
138. Nelson, E.R.; Habibi, H.R. Estrogen receptor function and regulation in fish and other vertebrates. Gen. Comp. Endocrinol. 2013, 192, 15-24. [CrossRef] [PubMed]

139. Teo, B.Y.; Tan, N.S.; Lim, E.H.; Lam, T.J.; Ding, J.L. A novel piscine vitellogenin gene: Structural and functional analyses of estrogen-inducible promoter. Mol. Cell. Endocrinol. 1998, 146, 103-120. [CrossRef]

140. Teo, B.Y.; Tan, N.S.; Lam, T.J.; Ding, J.L. Synergistic effects of nuclear factors-GATA, VBP and ER in potentiating vitellogenin gene transcription. FEBS Lett. 1999, 459, 57-63. [CrossRef]

141. Hawkins, M.B.; Thornton, J.W.; Crews, D.; Skipper, J.K.; Dotte, A.; Thomas, P. Identification of a third distinct estrogen receptor and reclassification of estrogen receptors in teleosts. Proc. Nat. Acad. Sci. USA 2000, 97, 10751-10756. [CrossRef] [PubMed]

142. Nelson, E.R.; Habibi, H.R. Functional significance of nuclear estrogen receptor subtypes in the liver of goldfish. Endocrinology 2010, 151, 1668-1676. [CrossRef] [PubMed]

143. Lu, H.; Cui, Y.; Jiang, L.; Ge, W. Functional analysis of nuclear estrogen receptors in zebrafish reproduction by genome editing approach. Endocrinology 2017, 158, 2292-2308. [CrossRef] [PubMed]

144. Tohyama, S.; Ogino, Y.; Lange, A.; Myosho, T.; Kobayashi, T.; Hirano, Y.; Yamada, G.; Sato, T.; Tatarazako, N.; Tyler, C.R.; et al. Establishment of estrogen receptor 1 (ESR1)-knockout medaka: ESR1 is dispensable for sexual development and reproduction in medaka, Oryzias latipes. Dev. Growth Differ. 2017, 59, 552-561. [CrossRef] [PubMed]

145. Nishimiya, O.; Katsu, Y.; Inagawa, H.; Hiramatsu, N.; Todo, T.; Hara, A. Molecular cloning and characterization of hagfish estrogen receptors. J. Steroid Biochem. Mol. Biol. 2017, 165, 190-201. [CrossRef] [PubMed]

146. Nishimiya, O.; Kunihiro, Y.; Hiramatsu, N.; Inagawa, H.; Todo, T.; Matsubara, T.; Reading, B.J.; Sullivan, C.V.; Hara, A. Molecular characterization and expression analysis of estrogen receptor and vitellogenins in inshore hagfish (Eptatretus burgeri). Indian J. Sci. Technol. 2011, 4, 194-195.

147. Schonbaum, C.P.; Lee, S.; Mahowald, A.P. The Drosophila yolkless gene encodes a vitellogenin receptor belonging to the low density lipoprotein receptor superfamily. Proc. Nat. Acad. Sci. USA 1995, 92, 1485-1489. [CrossRef] [PubMed]

148. Milla, S.; Mandiki, S.N.M.; Hubermont, P.; Rougeot, C.; Mélard, C.; Kestemont, P. Ovarian steroidogenesis inhibition by constant photothermal conditions is caused by a lack of gonadotropin stimulation in Eurasian perch. Gen. Comp. Endocrinol. 2009, 163, 242-250. [CrossRef] [PubMed]

149. Matsubara, T.; Nagae, M.; Ohkubo, N.; Andoh, T.; Sawaguchi, S.; Hiramatsu, N.; Sullivan, C.V.; Hara, A. Multiple vitellogenins and their unique roles in marine teleosts. Fish Physiol. Biochem. 2003, 28, 295-299. [CrossRef]

150. Finn, R.N.; Kristoffersen, B.A. Vertebrate vitellogenin gene duplication in relation to the "3R hypothesis": Correlation to the pelagic egg and the oceanic radiation of teleosts. PLoS ONE 2007, 2, e169. [CrossRef] [PubMed]

151. Williams, V.N.; Reading, B.J.; Hiramatsu, N.; Amano, H.; Glassbrook, N.; Hara, A.; Sullivan, C.V. Multiple vitellogenins and product yolk proteins in striped bass, Morone saxatilis: Molecular characterization and processing during oocyte growth and maturation. Fish Physiol. Biochem. 2014, 40, 395-415. [CrossRef] [PubMed]

152. Kolarevic, J.; Nerland, A.; Nilsen, F.; Finn, R.N. Goldsinny wrasse (Ctenolabrus rupestris) is an extreme vtgAa-type pelagophil teleost. Mol. Reprod. Dev. 2007, 75, 1011-1020. [CrossRef] [PubMed]

153. Finn, R.N.; Østby, G.C.; Norberg, B.; Fyhn, H.J. In vivo oocyte hydration in Atlantic halibut (Hippoglossus hippoglossus), proteolytic liberation of free amino acids, and ion transport, are driving forces for osmotic water influx. J. Exp. Biol. 2002, 205, 211-224. [PubMed]

154. Reading, B.J.; Williams, V.N.; Chapman, R.W.; Williams, T.I.; Sullivan, C.V. Dynamics of the striped bass (Morone saxatilis) ovary proteome reveal a complex network of the translasome. J. Proteome Res. 2013, 12, 1691-1699. [CrossRef] [PubMed]

155. Fabra, M.; Cerdà, J. Ovarian cysteine proteinases in the teleost Fundulus heteroclitus: Molecular cloning and gene expression during vitellogenesis and oocyte maturation. Mol. Reprod. Dev. Incorp. Gamete Res. 2004, 67, 282-294. [CrossRef] [PubMed]

156. Smolenaars, M.M.; Madsen, O.; Rodenburg, KW.; Van der Horst, D.J. Molecular diversity and evolution of the large lipid transfer protein superfamily. J. Lipid Res. 2007, 48, 489-502. [CrossRef] [PubMed] 
157. Anderson, A.J.; Arthington, A.H.; Anderson, S. Lipid Classes and Fatty Acid Composition of the Eggs of Some Australian Fish. Comp. Biochem. Physiol. 1990, 98, 267-270. [CrossRef]

158. Watanabe, T.; Lee, M.; Mizutani, J.; Yamada, T.; Satoh, S.; Takeuchi, T.; Yoshida, N.; Kitada, T.; Arakawa, T. Effective components in cuttlefish meal and raw krill for improvement of quality of red sea bream (Pagrus major) eggs. Nippon Suisan Gakkaishi 1991, 57, 681-694. [CrossRef]

159. Watanabe, T. Effect of broodstock diets on reproduction of fish. In Proceedings of the Advances in Tropical Aquaculture, Tahiti, French Polynesia, 20 February-4 March 1989.

160. Eskelinen, P. Effects of different diets on egg production and egg quality of Atlantic salmon (Salmo salar L.). Aquaculture 1989, 79, 275-281. [CrossRef]

161. Blom, J.H.; Dabrowski, K. Reproductive success of female rainbow trout (Oncorhynchus mykiss) in response to graded dietary ascorbyl monophosphate levels. Biol. Reprod. 1995, 52, 1073-1080. [CrossRef] [PubMed]

162. Sandnes, K.; Ulgens, Y.; Braekkan, O.R.; Utne, F. The effect of ascorbic acid supplementation in broodstock feed on reproduction of rainbow trout (Salmo gairdneri). Aquaculture 1984, 43, 167-177. [CrossRef]

163. Will, C.L.; Lührmann, R. Spliceosome structure and function. Cold Spring Harb. Perspect. Biol. 2010, 3, a003707. [CrossRef] [PubMed]

164. Ramachandra, R.K.; Salem, M.; Gahr, S.; Rexroad, C.E., III; Yao, J. Cloning and characterization of microRNAs from rainbow trout (Oncorhynchus mykiss): Their expression during early embryonic development. BMC Dev. Biol. 2008, 8, 41. [CrossRef] [PubMed]

165. Juanchich, A.; Le Cam, A.; Montfort, J.; Guiguen, Y.; Bobe, J. Identification of differentially expressed miRNAs and their potential targets during fish ovarian development. Biol. Reprod. 2013, 88, 128. [CrossRef] [PubMed]

166. Giraldez, A.J.; Cinalli, R.M.; Glasner, M.E.; Enright, A.J.; Thomson, J.M.; Baskerville, S.; Hammond, S.M.; Bartel, D.P.; Schier, A.F. MicroRNAs regulate brain morphogenesis in zebrafish. Science 2005, 308, 833-838. [CrossRef] [PubMed]

167. Jamnongjit, M.; Hammes, S.R. Ovarian steroids: The good, the bad, and the signals that raise them. Cell Cycle 2006, 5, 1178-1183. [CrossRef] [PubMed]

168. Bobe, J.; Nguyen, T.; Jalabert, B. Targeted gene expression profiling in the rainbow trout (Oncorhynchus mykiss) ovary during maturational competence acquisition and oocyte maturation. Biol. Reprod. 2004, 71, 73-82. [CrossRef] [PubMed]

169. Sriraman, V.; Eichenlaub-Ritter, U.; Bartsch, J.W.; Rittger, A.; Mulders, S.M.; Richards, J.S. Regulated expression of ADAM8 (a disintegrin and metalloprotease domain 8) in the mouse ovary: Evidence for a regulatory role of luteinizing hormone, progesterone receptor, and epidermal growth factor-like growth factors. Biol. Reprod. 2008, 78, 1038-1048. [CrossRef] [PubMed]

170. Kanamori, A. Systematic identification of genes expressed during early oogenesis in medaka. Mol. Reprod. Dev. 2000, 55, 31-36. [CrossRef]

171. Kawaguchi, M.; Yasumasu, S.; Shimizu, A.; Sano, K.; Iuchi, I.; Nishida, M. Conservation of the egg envelope digestion mechanism of hatching enzyme in euteleostean fishes. FEBS J. 2010, 277, 4973-4987. [CrossRef] [PubMed]

172. Lizé, M.; Klimke, A.; Dobbelstein, M. MicroRNA-449 in cell fate determination. Cell Cycle 2011, 10, $2874-2882$. [CrossRef] [PubMed]

173. Sonkoly, E.; Lovén, J.; Xu, N.; Meisgen, F.; Wei, T.; Brodin, P.; Jaks, V. MicroRNA-203 functions as a tumor suppressor in basal cell carcinoma. Oncogenesis 2012, 1, e3. [CrossRef] [PubMed]

174. Castets, M.D.; Schaerlinger, B.; Silvestre, F.; Gardeur, J.N.; Dieu, M.; Corbier, C.; Kestemont, P.; Fontaine, P. Combined analysis of Perca fluviatilis reproductive performance and oocyte proteomic profile. Theriogenology 2012, 78, 432-442. [CrossRef] [PubMed]

175. Schilling, J.; Nepomuceno, A.; Schaff, J.E.; Muddiman, D.C.; Daniels, H.V.; Reading, B.J. Compartment proteomics analysis of white perch (Morone americana) ovary using support vector machines. J. Proteome Res. 2014, 13, 1515-1526. [CrossRef] [PubMed]

176. Reading, B.J.; Chapman, R.W.; Schaff, J.E.; Scholl, E.H.; Opperman, C.H.; Sullivan, C.V. An ovary transcriptome for all maturational stages of the striped bass (Morone saxatilis), a highly advanced perciform fish. BMC Res. Notes 2012, 5, 111. [CrossRef] [PubMed]

(C) 2018 by the authors. Licensee MDPI, Basel, Switzerland. This article is an open access article distributed under the terms and conditions of the Creative Commons Attribution (CC BY) license (http://creativecommons.org/licenses/by/4.0/). 